\title{
Recent Developments in Targeting RAS Downstream Effectors for RAS-Driven Cancer Therapy
}

\author{
Ozge Tatli ${ }^{1,2}$ and Gizem Dinler Doganay ${ }^{1,3, *}$ \\ 1 Department of Molecular Biology, Genetics-Biotechnology, Graduate School, Istanbul Technical University, \\ Istanbul 34469, Turkey; tatlio@itu.edu.tr \\ 2 Department of Molecular Biology and Genetics, Istanbul Medeniyet University, Istanbul 34720, Turkey \\ 3 Department of Molecular Biology and Genetics, Istanbul Technical University, Istanbul 34469, Turkey \\ * Correspondence: gddoganay@itu.edu.tr; Tel.: +90-2122-857-256
}

check for

updates

Citation: Tatli, O.; Dinler Doganay,

G. Recent Developments in Targeting RAS Downstream Effectors for

RAS-Driven Cancer Therapy.

Molecules 2021, 26, 7561. https://

doi.org/10.3390/molecules26247561

Academic Editor: Roberta Bortolozzi

Received: 15 September 2021

Accepted: 11 October 2021

Published: 14 December 2021

Publisher's Note: MDPI stays neutral with regard to jurisdictional claims in published maps and institutional affiliations.

Copyright: (c) 2021 by the authors. Licensee MDPI, Basel, Switzerland. This article is an open access article distributed under the terms and conditions of the Creative Commons Attribution (CC BY) license (https:// creativecommons.org/licenses/by/ $4.0 /)$.

\begin{abstract}
Aberrant activity of oncogenic rat sarcoma virus (RAS) protein promotes tumor growth and progression. RAS-driven cancers comprise more than 30\% of all human cancers and are refractory to frontline treatment strategies. Since direct targeting of RAS has proven challenging, efforts have been centered on the exploration of inhibitors for RAS downstream effector kinases. Two major RAS downstream signaling pathways, including the Raf/MEK/Erk cascade and the phosphatidylinositol3-kinase (PI3K) pathway, have become compelling targets for RAS-driven cancer therapy. However, the main drawback in the blockade of a single RAS effector is the multiple levels of crosstalk and compensatory mechanisms between these two pathways that contribute to drug resistance against monotherapies. A growing body of evidence reveals that the sequential or synergistic inhibition of multiple RAS effectors is a more convenient route for the efficacy of cancer therapy. Herein, we revisit the recent developments and discuss the most promising modalities targeting canonical RAS downstream effectors for the treatment of RAS-driven cancers.
\end{abstract}

Keywords: RAS-driven cancers; RAS effectors; Raf/MEK/Erk; PI3K-mTOR

\section{Introduction}

Rat sarcoma virus (RAS) is involved in distinct cellular processes, including cell division, proliferation, migration and cellular differentiation. RAS is tethered to the plasma membrane and acts as a nexus to relay mitogenic stimuli from receptor tyrosine kinases (RTKs), thereby activating a plethora of downstream signaling pathways. RAS protooncogenes encode four members of evolutionary conserved, membrane-associated small GTP-binding proteins (HRAS, NRAS, KRAS4A, KRAS4B). The activity of RAS is tightly regulated by a molecular switch between GTP-bound active and GDP-bound inactive conformation. Two classes of regulatory proteins maintain the GTPase activity of RAS proteins: guanine exchange factors (GEFs) catalyze the exchange of GDP for GTP, and GTPase activating proteins (GAPs) dictate the spatial regulation of RAS by accelerating the hydrolysis of bound GTP to GDP and inorganic phosphate [1].

RAS hyperactivation is frequently observed in a large spectrum of cancer types, including pancreatic ductal adenocarcinomas (PDACs), colorectal myelomas, lung adenocarcinomas and endometrial carcinomas. RAS-activating mutations and epidermal growth factor (EGF) hyper-signaling, which potentiates cell proliferation, are common in cancer. RAS proteins are overactive in nearly $30 \%$ of all cancers and are associated with resistance to frontline monotherapies [2]. Among RAS isoforms, KRAS mutations are most frequently found in pancreatic, colorectal and lung adenocarcinomas, while NRAS and HRAS are generally mutated in some melanomas, leukemias and thyroid cancers [3]. Mostly, RAS genes harbor oncogenic mutations which abrogate intrinsic GTPase activity of RAS protein and drive tumorigenesis. In all three RAS isoforms, G12, G13 and Q61 sites are the three mutational hotspots, which consist of $98 \%$ of all known RAS mutations. Mutations on 
these sites lead to the expression of constitutively active RAS proteins that induce cellular transformation and tumorigenesis [4,5]. Except for these mutations, abnormal activity of RAS can also arise from GDP-GTP deregulation, loss of GAPs or RTK-mediated activity of GEFs.

In the last three decades, tremendous efforts have been expended on targeting RASdriven tumors. In an effort to inhibit mutant RAS function, RAS can be directly targeted by molecules disrupting its interaction with SOS1 (SOS Ras/Rac Guanine Nucleotide Exchange Factor 1) or with its effectors such as Raf and PI3K (phosphatidylinositol-3-kinase). However, RAS proteins are often termed "undruggable" due to the consecutive failures in the development of direct RAS inhibitors. Various alternative ways to battle against this perception have been implemented [6-8]. Thus far, only the KRAS ${ }^{\mathrm{G} 12 \mathrm{C}}$ mutant has been tractable in blocking the oncogenic signal [9-12]. In 2013, Ostrem et al. demonstrated that mutant RAS can be selectively targeted through a new allosteric regulatory site defined on RAS. The researchers identified a covalent compound that could bind to the mutant cysteine on KRAS ${ }^{\mathrm{G} 12 \mathrm{C}}$ via a disulfide bond and inhibit SOS1-catalyzed nucleotide exchange [13]. In the search for an inhibitor with a better binding and pharmacologic property, ARS-1620 has been developed as a RAS inhibitor [12] and revealed variable responses in a panel of KRAS ${ }^{\mathrm{G} 12 \mathrm{C}}$ mutant cell lines, which can be enhanced by concomitant inhibition of the PI3K cascade [14,15]. Further, newer molecules sotorasib (AMG-510) and adagrasib (MRTX849), which are structural derivatives of ARS-1620 with enhanced sensitivity, have been developed and entered the clinic [9]. However, given the variability of response in tumor models, direct KRAS ${ }^{\mathrm{G} 12 \mathrm{C}}$ inhibitors will not likely confer a benefit to a significant number of patients.

Oncogenic RAS signaling can be blocked indirectly by targeting the attachment of RAS to the inner plasma membrane or inhibiting RAS-dependent metabolic processes such as autophagy and macropinocytosis [16]. A variety of post-translational modifications of cytosolic precursor RAS protein regulate its membrane association and activation. These modifications include prenylation, post-prenylation, palmitoylation, ubiquitination, phosphorylation, SUMOylation, acetylation, nitrosylation, etc. Among them, the processes of prenylation and post-prenylation that mediate membrane localization are major potential therapeutic targets [17]. In particular, molecules targeting farnesylation of RAS via CAAX mimetic polypeptides or farnesyl pyrophosphate analogs have been clinically evaluated for the treatment of RAS-mutant advanced solid cancer $[18,19]$. However, the effectiveness of these inhibitors for RAS-driven solid cancer has been less than favorable in single-agent settings. Similarly, a number of studies show that the inhibition of one particular modification remains insufficient to prevent tumorigenesis [20,21].

Targeting RAS effector signaling cascades or synthetic lethal interactors of mutant RAS are other indirect strategies being pursued to conquer RAS-mutant cancers [22]. The former is one of the most dynamic arms in the development of RAS-inhibitory molecules. However, RAS downstream effector signaling is far from consisting of linear unidirectional cascades. Conversely, it can adapt and rewire in response to the blockage of specific nodes. Therefore, cancer cells develop dependencies upon inhibition of only RAS or a single RAS effector, which contribute to acquired drug resistance in single-agent therapies. For the efficacy of cancer therapy, synergistic inhibition of specific targets is increasingly adopted to block compensatory mechanisms between these two pathways. Despite the advances in targeted therapies in the treatment of cancer, acquisition of drug resistance still remains a major drawback. In this review, we revisit the recent strategies and discuss the most promising approaches targeting canonical RAS downstream effectors for the treatment of RAS-induced cancers.

\section{Overview of the Downstream Signaling Pathways of RAS}

RAS engages with two major downstream effector signaling pathways, including Raf/MEK/Erk (MAPK) and phosphatidylinositol-3-kinase (PI3K) cascades. These pathways are associated with specific cancer-related phenotypes, including transcriptional 
reprogramming, promoted cell survival and proliferation, suppressed apoptosis and enhanced invasiveness of the cells [23]. Mitogenic signals from upstream growth factor receptors are transmitted into cells by RAS proteins. RAS proteins attach to the plasma membrane with a process facilitated by several post-translational modifications. A farnesyl isoprenoid moiety is added to RAS by farnesyltransferase (FTs) to increase its hydrophobicity and enable its association with the plasma membrane [24]. Membrane-anchored RAS is activated by GTP loading and serves as an activator for effector kinases by recruiting them to the cell membrane, where further phosphorylation events enable their subsequent activation [25]. GTP-loaded RAS proteins can activate both PI3K/Akt/mTOR and Raf/MEK/Erk signaling cascades, which are compelling therapeutic targets as major mediators of RAS-induced oncogenic signal transduction (Figure 1).

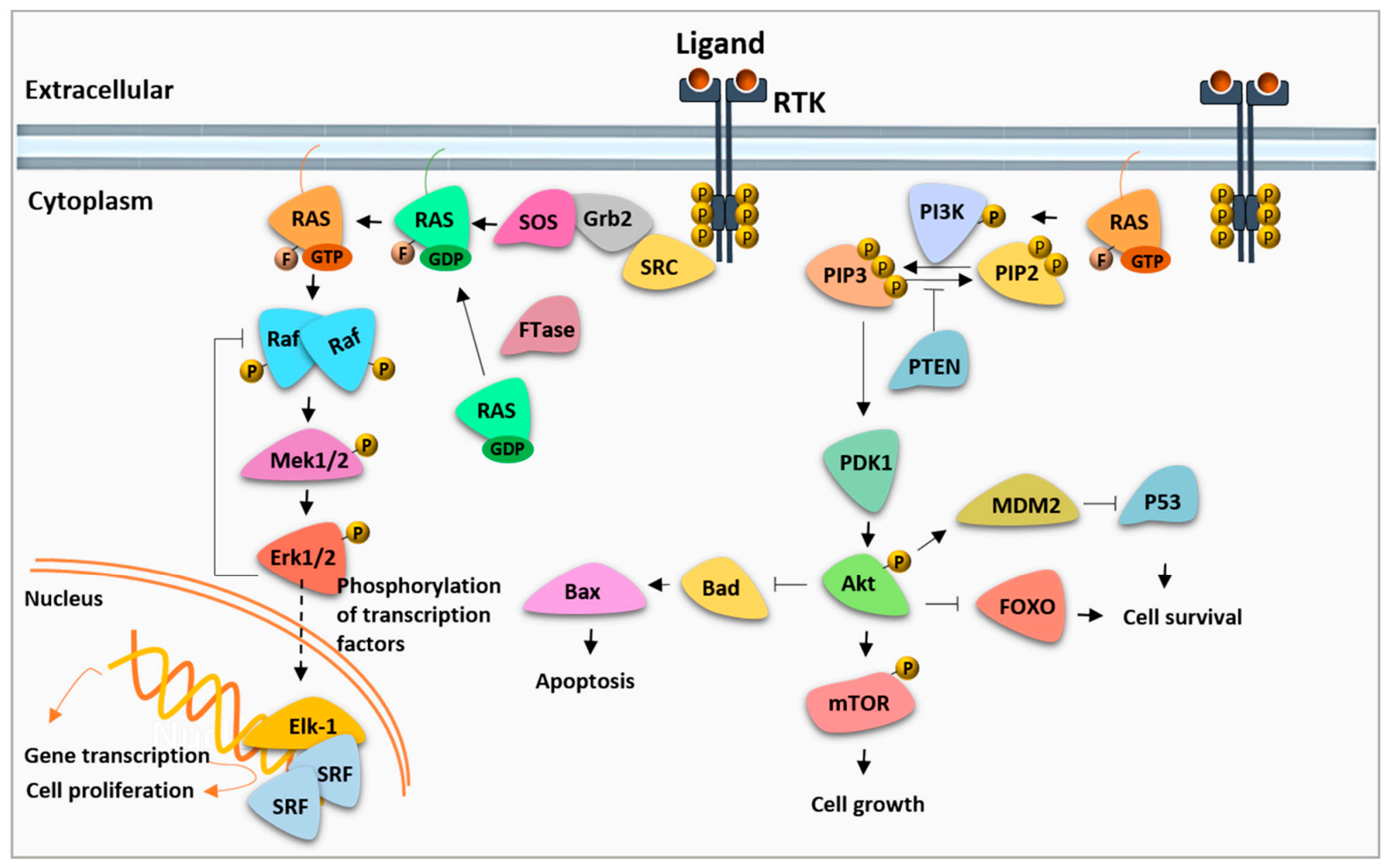

Figure 1. Ras/Raf/MEK/Erk and PI3K/mTOR signaling pathways.

The RAS-Erk signaling network, which is the central regulator for cell cycle progression and proliferation, is a prominent mediator of RAS-dependent cancer growth. RAS stimulates cell proliferation by increasing the concentration of Raf kinases to the plasma membrane, where effector kinases are activated [26]. Here, active RAS drives Raf dimerization by promoting conformational changes, which further trigger dephosphorylation of the inhibitory sites and phosphorylation of activatory sites [27]. Active Raf in turn activates MEK through phosphorylation, which results in the final activation of Erk. Following activation, Erk translocates to the nucleus, where it activates several transcription factors and cell cycle regulatory proteins. The cascade is modulated by a large number of factors $[28,29]$. Particularly, Erk does not only activate its downstream substrates, but also inhibits the upstream kinases in the MAPK pathway through phosphorylation. Thus, it can modulate the pathway both negatively and positively through feedback inhibition. Among the three MAP kinases, Raf kinases are the most critical effectors in KRAS-driven cancers. B-Raf is one of the most mutated Raf isoforms in cancerous cells. The well-known 
driver mutation in B-Raf occurs at the position of V600. In this mutant form, B-Raf is constitutively active, independent of upstream cues [30,31].

The other well-described downstream pathway of RAS is the PI3K-mTOR signaling cascade, which controls a number of cellular events including cell cycle progression, protein synthesis, metabolism and survival [32]. PI3K signaling can be activated by RAS, receptor tyrosine kinases (RTKs) or G protein-coupled receptors (GPCRs). Phosphatidylinositol kinases (PI3K) are intracellular lipid kinases that phosphorylate phosphoinositides and generate biologically active phosphatidylinositol 3,4,5-triphosphate (PIP3). PIP3 recruits PDK1 and Akt to the plasma membrane, where they are subsequently activated. Active Akt propagates signals to several substrates, including mammalian target of rapamycin (mTOR), forkhead box $\mathrm{O}(\mathrm{FOXO})$ or nuclear factor (NF)- $\mathrm{B}$, which induce the protein synthesis, cell growth and glucose and lipid metabolism. The pathway is negatively regulated by lipid phosphatase PTEN, which dephosphorylates PIP3 and thereby reduces the level of phosphorylated Akt. Once Akt is deactivated by protein phosphatases PHLPP1/2 and PP2A, the signaling events are terminated [33,34]. Both RAS effector pathways are modulated by a series of protein kinases, phosphatases and multiple exchange proteins, and they influence each other in both negative and positive ways. Therefore, in the case of chemical inhibition of one pathway, the effect of the inhibitor is compensated in the cell by the activation of the other pathway [35-38]. Single-agent therapies generally fail to produce durable responses due to the incomplete apoptosis and development of resistance to the targeted agent by compensatory mechanisms $[39,40]$. The crosstalk between these two pathways forms a basis for combinatorial therapies in cancer progression [36]. Therefore, delineating the intricate underlying molecular mechanisms of the extensive crosstalk between these signaling cascades is of great importance for effective targeted therapeutic strategies.

\subsection{Raf Inhibitors}

So far, three B-Raf kinase inhibitors, including vemurafenib [41,42], dabrafenib [43,44] and encorafenib [45], have been clinically approved by the US Food and Drug Administration (FDA) for selective inhibition of kinase activity in B-Raf ${ }^{\mathrm{V} 600}$ mutant-driven melanoma. These inhibitors hinder catalytically active B-Raf ${ }^{\mathrm{V} 600}$ mutant monomers with specificity for the ATP-binding site, but not non-V600 mutants [46-48]. However, monotherapy with these inhibitors has been shown to promote paradoxical activation of Erk by inducing wild-type Raf dimerization in non-tumorous cells and also RAS-induced tumors which signal through Raf dimers [49]. When Raf proteins are dimerized, the inhibitor-bound Raf protomer allosterically transactivates the other Raf component of the dimer, thereby resulting in the final activation of Erk.

In the presence of oncogenic RAS, B-Raf inhibition has been shown to lead to the formation of RAS-dependent B-Raf/C-Raf heterodimers and drive tumorigenesis through C-Raf activation [50]. A significant number of patients on B-Raf-inhibitor therapy developed secondary malignancies, most commonly cutaneous squamous-cell carcinomas (cuSCC), due to the intrinsic or acquired drug resistance at tolerable doses [51]. Thus, B-Raf inhibitors alone have not been used effectively for the therapy of RAS-addicted cancers. Instead, combining B-Raf inhibitors with MEK inhibitors has been shown to be useful not only to provide a better survival outcome, but also to reduce the incidence of cuSCC [52,53].

In an effort to suppress B-Raf activity without stimulating cancer growth, secondgeneration Raf inhibitors including type II pan-Raf inhibitors and paradox-breakers were developed to hinder dimerization-driven transactivation. These inhibitors possess minimal paradoxical activation compared to approved B-Raf ${ }^{\mathrm{V} 600}$ inhibitors through distinct mechanisms [54]. Of note, the major concern for the clinical use of pan-Raf inhibitors is their lack of selectivity for mutant B-Raf, which might cause toxicity resulting from the blockade of MAPK signaling in normal tissue. Pan-Raf inhibitors bind to both protomers in Raf dimers and lock them in an $\alpha$-helix-in, DFG-out conformation [55,56]. Examples of pan-Raf inhibitors include sorafenib, belvarafenib, AZ-628, CCT196969, CCT241161, 
LY3009120, LXH254 and TAK-580. Apart from these, CCT3833 works as a dual pan-Raf inhibitor by inhibiting both Raf and upstream kinases of RAS, thereby preventing RAS activation by the relief of negative feedback loops [57,58]. Several pan-Raf inhibitors showed promising results in preclinical models of cancers bearing RAS mutations, including melanoma [54], acute myeloid leukemia (AML) [59], colorectal cancer [60], multiple myeloma [61,62], pancreatic cancer [63] and thyroid cancer [64], and are currently under clinical evaluation. Dual pan-Raf inhibitors, CCT196969 and CCT241161, that also target SRC (SRC Proto-Oncogene, Non-Receptor Tyrosine Kinase) as one of major MAPKs regulatory protein tyrosine kinases, inhibited the growth of NRAS-mutant melanoma cells and achieved tumor regression in patient-derived xenografts that are resistant to B-Raf inhibitors. These findings suggested that they could provide clinical benefit in melanoma patients with NRAS mutations as a first-line therapy and in relapsed patients as a secondline therapy [65]. However, it is important to take into account that benefits in preclinical studies have not always translated into clinical success. For example, LY3009120 has been shown to be effective in numerous in vitro studies and preclinical models $[60,63,66]$, but exhibited unexpectedly limited pharmacodynamic effects at its maximum tolerated dose in patients with B-Raf or KRAS mutations (NCT02014116) [67]. Unlike LY3009120, CCT3833 significantly prolonged the survival of a patient with KRAS ${ }^{\mathrm{G} 12 \mathrm{~V}}$ mutant spindle cell sarcoma which was refractory to multi-kinase inhibitor treatment in a phase I clinical trial (NCT02437227) [68]. Similarly, another pan-Raf inhibitor, lifirafenib (BGB-283), elicited an acceptable safety profile and clinical efficacy in patients with KRAS-mutated NSCLC and endometrial cancer (NCT02610361) [69]. These results have encouraged a phase I/II trial of lifirafenib in combination with the MEK inhibitor mirdametinib (PD-0325901) in patients with B-Raf- and RAS-mutant tumors (NCT03905148). In addition, LXH254, a novel type II pan-Raf inhibitor developed by Novartis, has been shown to be potent, selective, efficient and well-tolerated in RAS-mutant xenograft models [70]. Moreover, LXH254 inhibited long-term cell viability in NRAS-mutant NSCLC cells when combined with volasertib, a polo-like kinase inhibitor [71]. LXH254 is being further investigated in combination with a MEK inhibitor (trametinib), an Erk inhibitor (LTT462) or a CDK inhibitor (ribociclib) in patients with NRAS mutant melanoma (NCT02974725, NCT04417621). Another pan-Raf inhibitor, Belvarafenib, demonstrated anti-tumor activity as a single agent and has been found to be well-tolerated in patients with Raf or RAS mutations (NCT03118817) [72]. Clinical studies utilizing pan-Raf inhibitors in combination with other therapeutic agents to improve the response rate within patients with RAS mutations are ongoing (NCT02607813, NCT04835805, NCT04059224, NCT03284502).

The efficacy of pan-Raf inhibitors is promising, but nevertheless not striking for antiRAS cancer therapy, which requires excellent drug combination for a robust response from dozens of alternatives. In this regard, Rukhlenko et al. built a system biology-based dynamic model to analyze the synergy of Raf inhibitor combinations in an oncogenic RAS and/or B-Raf ${ }^{\mathrm{V} 600 \mathrm{E}}$ background, taking into account the thermodynamics and kinetics of inhibitor-protein interactions, post-translational modifications and structural determinants [73]. They found that two distinct conformation-specific kinase inhibitors targeting the same kinase but in different conformations could block the paradoxical activation. The synergy of structurally different Raf inhibitors was validated in mutant NRAS, HRAS and BRaf ${ }^{\mathrm{V} 600 \mathrm{E}}$ cells [73]. The data demonstrated that the combination of an $\alpha-\mathrm{C}$ helix in/DFG loop-out inhibitor (e.g., sorafenib, LY3009120) and an $\alpha$-C helix-out/DFG loop-in inhibitor (e.g., vemurafenib or dabrafenib) has effectively targeted cells with both B-Raf ${ }^{\mathrm{V} 600 \mathrm{E}}$ and RAS mutations [73], thus providing a potential to target tumors with such genetic backgrounds.

Another class of B-Raf inhibitors, paradox breakers, have been developed utilizing the structure of vemurafenib as a skeleton, with various chemical modifications (Table 1 and Table S1). Candidate compounds were screened for hindering B-Raf ${ }^{\mathrm{V} 600 \mathrm{E}}$ and evaluating pathway reactivation in RAS-mutant cell lines. These inhibitors dock on Raf proteins to impair Raf dimerization [74-76] and prevent the formation of B-Raf/C-Raf heterodimers observed in 
RAS-mutant tumors treated with first-generation Raf inhibitors [56]. The paradox breakers, PLX7904 and PLX8394, have been reported to possess a more durable efficacy in cuSCC mouse cells with a HRAS ${ }^{\mathrm{Q} 61 \mathrm{~L}}$ mutation, compared to vemurafenib [76]. In a later study, it has been shown that PLX8394 is able to selectively disrupt B-Raf homodimers and BRaf/C-Raf heterodimers, but C-Raf homodimers are unresponsive to PLX8394 due to its inability to selectively bind C-Raf [77]. Given that C-Raf fusions can activate both the MAPK and PI3K/mTOR signaling cascades, the efficacy of these drugs most likely will not be sufficient in a single-agent setting for the treatment of tumors driven by RAS mutations due to the possible induction of C-Raf fusion formation.

Table 1. Representative inhibitors targeting rat sarcoma virus (RAS) downstream effectors.

\begin{tabular}{|c|c|c|c|}
\hline Name & Potency & Target & Structure \\
\hline $\begin{array}{l}\text { Dabrafenib/ } \\
\text { GSK2118436 }\end{array}$ & $\begin{array}{c}\mathrm{IC}_{50}: 0.6 \mathrm{nM}\left(\mathrm{B}-\mathrm{Raf}^{\mathrm{V} 600 \mathrm{E}}\right) \\
\mathrm{IC}_{50}: 5 \mathrm{nM}(\mathrm{C}-\mathrm{Raf})\end{array}$ & Raf & \\
\hline PLX7904 & $\mathrm{IC}_{50}: 5 \mathrm{nM}\left(\mathrm{B}-\mathrm{Raf}^{\mathrm{V} 600 \mathrm{E}}\right)$ & B-Raf ${ }^{\mathrm{V} 600 \mathrm{E}}$ & \\
\hline $\begin{array}{l}\text { CH5126766/ } \\
\text { RO5126766 }\end{array}$ & $\begin{array}{c}\mathrm{IC}_{50}: 8.2 \mathrm{nM}\left(\mathrm{B}-\mathrm{Raf}^{\mathrm{V} 600 \mathrm{E}}\right) \\
\mathrm{IC}_{50}: 190 \mathrm{nM}(\mathrm{B}-\mathrm{Raf}) \\
\mathrm{IC}_{50}: 56 \mathrm{nM}(\mathrm{C}-\mathrm{Raf}) \\
\mathrm{IC}_{50}: 160 \mathrm{nM}(\mathrm{MEK})\end{array}$ & Raf and MEK1/2 & \\
\hline $\begin{array}{l}\text { Trametinib/ } \\
\text { GSK1120212 }\end{array}$ & $\begin{array}{c}\mathrm{IC}_{50}: \\
0.92 \mathrm{nM} / 1.8 \mathrm{nM} \\
(\mathrm{MEK} 1 / 2)\end{array}$ & Mek1/2 & \\
\hline $\begin{array}{l}\text { Selumetinib/ } \\
\text { AZD6244 }\end{array}$ & $\begin{array}{l}\mathrm{IC}_{50}: 14 \text { nM (MEK1) } \\
\text { Kd: } 530 \text { nM (MEK2 }\end{array}$ & MEK1/2 & \\
\hline $\begin{array}{l}\text { Ulixertinib / } \\
\text { BVD-523 }\end{array}$ & $\mathrm{IC}_{50}:<0.3 \mathrm{nM}($ Erk2) & Erk1/2 & \\
\hline
\end{tabular}

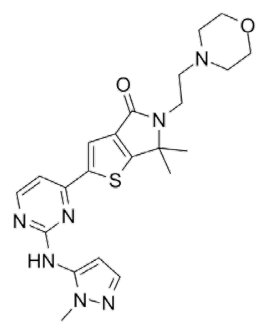


Table 1. Cont.

\begin{tabular}{|c|c|c|c|}
\hline Name & Potency & Target & Structure \\
\hline $\begin{array}{c}\text { Copanlisib / } \\
\text { BAY } 80\end{array}$ & $\begin{array}{l}\mathrm{IC}_{50}: 0.5 \mathrm{nM}(\mathrm{PI} 3 \mathrm{~K} \alpha) \\
\mathrm{IC}_{50}: 0.7 \mathrm{nM}(\mathrm{PI} 3 \mathrm{~K} \delta) \\
\mathrm{IC}_{50}: 3.7 \mathrm{nM}(\mathrm{PI} 3 \mathrm{~K} \beta) \\
\mathrm{IC}_{50}: 6.4 \mathrm{nM}(\mathrm{PI} 3 \mathrm{~K} \gamma)\end{array}$ & Pan-PI3K & \\
\hline MK-2206 & $\begin{array}{l}\mathrm{IC}_{50}: 8 \mathrm{nM}(\text { Akt1) } \\
\mathrm{IC}_{50}: 12 \mathrm{nM}(\text { Akt2) } \\
\mathrm{IC}_{50}: 65 \mathrm{nM}(\text { Akt } 3)\end{array}$ & Akt & \\
\hline AZD8055 & $\mathrm{IC}_{50}: 0.8 \mathrm{nM}(\mathrm{mTOR})$ & mTORC1 and mTORC2 & \\
\hline
\end{tabular}

Transmission of signals from B-Raf to MEK requires the dimerization of B-Raf protomers in both normal cells and non-B-Raf ${ }^{\mathrm{V} 600}$ tumor cells [78]. To circumvent the transactivation of Raf dimers elicited by current Raf inhibitors, the dimer interface can be targeted by allosteric B-Raf inhibitors, thereby eliminating overactive MAPK signaling induced by oncogenic B-Raf or RAS. The dimer interface of B-Raf protomers exists in the kinase domain of B-Raf at the C-terminal end of the $\alpha \mathrm{C}$ helix. R509 residue plays the central role to provide dimer integrity. Mutations in R509/L515/M517 residues have been shown to completely block the activity of wild-type B-Raf [79]. To target B-Raf dimers, Beneker et al. have developed type IV inhibitors and designed a dimeric disrupter peptide to allosterically inhibit Raf kinase activity. This strategy enabled the blockade of paradoxical activation induced by vemurafenib [80]. Similarly, Gunderwala et al. have shown that in silico designed B-Raf dimer-breaking peptides induce proteasome-mediated degradation of B-Raf and inhibit kinase activity in KRAS mutant tumor cells. Additionally, a combination of these peptides with ATP-competitive inhibitors provided a by-pass of the cellular compensatory mechanisms caused by ATP-competitive Raf inhibitors [81]. In a subsequent study, Raf dimer breaker has been shown to be active against oncogenic B-Raf ${ }^{\mathrm{D} 594 \mathrm{G}}$ :C-Raf dimers [82], thus providing further evidence that allosteric type IV inhibitors targeting the Raf dimer interface have potential to be developed as an anticancer drug.

Among Raf isoforms, B-Raf has taken the center stage in targeted cancer therapy due to its high incidence of mutations in various types of cancer. Remarkably, another member of the Raf family, C-Raf (also known as Raf1), has been shown to have an essential role to relay upstream signals to MEK and Erk in K-RAS ${ }^{\mathrm{G} 12 \mathrm{~V}}$-addicted non-small-cell lung cancer (NSCLC) in mice. While the ablation of C-Raf from these cells inhibited tumor development, B-Raf did not show the same effect, indicating that the loss of C-Raf cannot be compensated by other Raf isoforms in K-RAS ${ }^{\mathrm{G} 12 \mathrm{~V}}$-addicted NSCLCs [83]. In line with this finding, systemic ablation of C-Raf and EGFR has been shown to induce tumor regression in pancreatic ductal adenocarcinoma models with KRAS/Trp53 mutations [84]. The loss of C-Raf expression did not affect MAPK signaling and possessed limited toxicity in mice [85]. Disappointingly, Morgan et al. have recently reported that selective inhibition of C-Raf elicited transactivation in engineered HCT116 KRAS ${ }^{\mathrm{G} 13 \mathrm{D}}$-mutant cells [86]. Therefore, as McCornick pointed out, targeting the stability of C-Raf and triggering its degradation might be an alternative strategy to avoid promoted paradoxical activation [87]. On the other side, Nolan et al. have recently reviewed the kinase-independent functions of C-Raf and explored targeting its effectors, in particular proapoptotic proteins ASK1 and MST2, and suggested that disruption of these protein-protein interactions or design of kinase 
activators in the context of ASK1 or MST2 activation might be a new avenue for anti-RAS cancer therapy [88].

\subsection{MEK Inhibitors}

Since attempts to target Raf kinases have suffered from acquired drug resistance that limits the effectiveness of inhibitors, the attention turned to the inhibition of MEK kinase. Many kinase inhibitors have been developed to compete for ATP by directly binding to this conserved site, which limits the selectivity of the molecule. Therefore, a number of allosteric MEK inhibitors have been developed for enhanced selectivity. These MEK inhibitors bind to a unique site close to the ATP-binding pocket of MEK, not competitively to the ATP-binding site. Thus, allosteric MEK inhibitors only bind to MEK selectively and inhibit the function of the kinase by inducing a conformational change that locks the enzyme in a catalytically inactive state [89]. High selectivity yields lower toxicity, and improved physicochemical properties. Three allosteric MEK inhibitors, trametinib, cobimetinib and binimetinib, are approved for treatment of patients with B-RafV ${ }^{600 E / K}$ melanoma. However, tumor responses to MEK inhibitors have been generally transient due to the rapid emergence of resistance in RAS-addicted cancers. Furthermore, in a subset of cancers in which MEK inhibitors have shown a notable clinical activity, patients have suffered from off-target effects, including dermatological and gastrointestinal toxicities [90]. Inhibition of MEK has been reported to lead to some resistance mechanisms, including the feedback activation of the PI3K pathway [91] and reactivation of the MAPK pathway [92,93]. The former has been shown to be stronger in RAS-mutant cancers. The difference in the sensitivity to MEK inhibitors between RAS- and B-Raf-mutant cancers might arise from the level of dependency on Erk-mediated mTORC1 activation in tumors bearing RAS mutations [94]. For example, trametinib has failed to confer a superior clinical benefit against KRASmutant NSCLC over docetaxel alone (NCT01362296) [95]. Similarly, selumetinib, which is an oral, potent MEK inhibitor, has not shown a significant efficacy in the treatment of NSCLC with KRAS mutations (NCT01229150, NCT01933932) [96,97]. In NRAS-mutant melanoma patients, Binimetinib treatment also did not provide any measurable benefit as monotherapy (NCT01763164) [98]. However, KRAS ${ }^{\mathrm{G} 12 \mathrm{C}}$ tumors have been shown as more sensitive to selumetinib compared to KRAS ${ }^{\mathrm{G} 12 \mathrm{D}}$ in lung cancer mouse models. This finding underscores the heterogeneity of tumors harboring different KRAS mutations [99].

Due to the limited efficacy of MEK inhibitors in mono-agent settings, efforts have focused on the development of combinatorial strategies. MEK inhibitors have been used in combination with other treatment modalities in RAS-mutant cancers, such as conventional chemotherapeutic agents [100], systemic immunotherapies [101,102] and Raf inhibitors $[103,104]$ to sustain a prolonged clinical benefit. Combined treatment of trametinib and immunomodulatory antibodies has shown preclinical efficacy in KRAS/p53-mutant lung cancer, suggesting a potential therapeutic approach using MEK inhibitors and immunotherapies [105]. The inactivation of zeste homolog 2 enhancer (EZH2), which is a histone methyltransferase regulating the expression of a variety of genes, has been linked to RAS signaling [106]. Owing to this, Lorenz Berg et al. have shown that RAS-mutant myeloid leukemia cells were sensitized to MEK inhibitors upon EZH2 inactivation. Thus, co-inhibiting EZH2 and MEK might provide a novel therapeutic route for RAS-driven cancers [107]. BI-3406, a novel SOS1-KRAS interaction inhibitor designed to target the catalytic domain of SOS1, has been combined with trametinib and sensitized KRAS-driven cancers to MEK inhibition in mouse models. MEK-induced drug resistance was attenuated in both G12 and G13 variants, which account for $80 \%$ of all KRAS-dependent cancers [108]. Similarly, co-targeting MEK and SHP2, which is required for RAS activation, has provided clinical utility and impaired cancer cell growth in both in vitro and in vivo settings of KRAS-mutant pancreatic cancer and NSCLC [109] and gastroesophageal cancer [110].

A unique Raf/MEK inhibitor, VS-6766/CH5126766, has shown activity in xenograft models of RAS-mutated cancers [111,112]. In parallel, combined treatment with VS6766/CH5126766 and AXL inhibitor (bemcentinib) has provided a stronger blockage 
of tumor growth in KRAS-mutant ovarian cancer cells with overexpressed AXL [113]. This allosteric inhibitor prevents the release of MEK from Raf, and thus blocks the subsequent phosphorylation of both MEK and Erk [114]. VS-6766/CH5126766 has recently gone to clinical trials in patients with KRAS-addicted lung and gynecological cancers. Initial results from the phase 1 dose-escalation and basket dose-expansion study have been encouraging due to the tolerability and clinical activity of VS-6766/CH5126766 in patients (NCT02407509) [115]. From the same trial, it has been recently reported that VS-6766 is effective in halting cancers with non-G12C-KRAS mutations when administered in an intermittent schedule [116]. The intermittent regimen has been previously shown to improve the pharmacokinetic/pharmacodynamic profile of VS-6766 compared to continuous dosing schedules [117]. Since the therapeutic index of single-agent inhibitors is narrow in particularly RAS-driven cancers, these findings are among the most promising, reported as single-agent therapy in cancers with RAS mutations. On the basis of these findings, multiple strategies using VS-6766/CH5126766 alone (NCT03681483) or with other agents such as defactinib (NCT03875820, NCT04625270, NCT04620330) are currently under clinical investigation in cancers with KRAS mutations. Furthermore, a great majority of ongoing clinical trials are testing MEK inhibitors with or without other agents in the treatment of RAS-mutant cancers (Table 2). Among them, the CDK4/6 inhibitor palbociclib is of particular interest in RAS-mutant NSCLC due to its sensitizing role to MEK inhibitors [118]. Given that cyclin-dependent kinases (CDKs) are frequently altered in most human cancers, patients may benefit from the therapeutic use of CDK inhibitors in combination with MEK inhibitors [119].

Table 2. Active or recruiting clinical trials for the treatment of RAS mutant cancers.

\begin{tabular}{|c|c|c|c|}
\hline Clinical Trial & Therapy & Phase & Genomic Profile \\
\hline \multicolumn{4}{|c|}{ MEK Inhibitors } \\
\hline NCT03714958 & $\begin{array}{l}\text { Trametinib and HDM201 (p53 } \\
\text { MDM2 inhibitor) }\end{array}$ & 1 & $\begin{array}{l}\text { RAS/Raf Mutant and TP53 Wild-type } \\
\text { Advanced/Metastatic Colorectal Cancer }\end{array}$ \\
\hline NCT03875820 & VS-6766 and Defactinib & 1 & Advanced RAS-mutant Solid Tumors \\
\hline NCT04303403 & Trametinib and Ruxolitinib & 1 & $\begin{array}{c}\text { Advanced RAS-mutant Colorectal Cancer and } \\
\text { Pancreatic Adenocarcinoma }\end{array}$ \\
\hline NCT03932253 & FCN-159 & 1 & $\begin{array}{c}\text { Advanced Melanoma Harboring } \\
\text { NRAS-aberrant (Ia) and NRAS-mutant (Ib) }\end{array}$ \\
\hline NCT01740648 & $\begin{array}{l}\text { Trametinib Fluorouracil } \\
\text { radiation therapy }\end{array}$ & 1 & KRAS, B-Raf and NRAS-mutant Rectal Cancers \\
\hline NCT03681483 & VS-6766 & 1 & $\begin{array}{l}\text { Advanced KRAS-mutant Lung } \\
\text { Adenocarcinomas }\end{array}$ \\
\hline NCT03990077 & HL-085 and Docetaxel & 1 & KRAS-mutant NSCLC \\
\hline NCT03299088 & $\begin{array}{l}\text { Trametinib and } \\
\text { Pembrolizumab }\end{array}$ & 1 & Advanced KRAS-mutant NSCLC \\
\hline NCT02607813 & LXH254 and PDR001 & 1 & $\begin{array}{l}\text { KRAS-mutant NSCLC, } \\
\text { NRAS-mutant Melanoma }\end{array}$ \\
\hline NCT02407509 & VS-6766 w / o Everolimus & 1 & Solid Tumors or Multiple Myeloma $[115,116]$ \\
\hline NCT03704688 & Trametinib and Ponatinib & $1 / 2$ & KRAS-mutant Advanced NSCLC \\
\hline NCT03170206 & Binimetinib and Palbociclib & $1 / 2$ & Advanced KRAS-mutant NSCLC \\
\hline NCT02022982 & PD-0325901 and Palbociclib & $1 / 2$ & KRAS-mutant NSCLC, solid tumors \\
\hline NCT03973151 & HL-085 & $1 / 2$ & NRAS-mutant Advanced Melanoma \\
\hline NCT04409639 & Cobimetinib & 2 & $\begin{array}{l}\text { Newly Diagnosed or HMA-treated CMML } \\
\text { Patients with RAS Pathway Mutations }\end{array}$ \\
\hline
\end{tabular}


Table 2. Cont.

\begin{tabular}{cccc}
\hline Clinical Trial & Therapy & Phase & Genomic Profile \\
\hline NCT01320085 & Binimetinib & 2 & $\begin{array}{c}\text { Locally Advanced and Unresectable or } \\
\text { Metastatic Malignant Cutaneous Melanoma, } \\
\text { Harboring B-Raf } \text { V00 }_{\text {or NRAS Mutations [120] }}\end{array}$ \\
\hline NCT04620330 & VS-6766 w/o Defactinib & 2 & Recurrent KRAS-mutant (KRAS-mt) NSCLC \\
\hline NCT04625270 & VS-6766 w/o Defactinib & 2 & $\begin{array}{c}\text { Recurrent Low-Grade Serous Ovarian } \\
\text { Cancer (KRAS-mt) }\end{array}$ \\
\hline NCT03981614 & $\begin{array}{c}\text { Binimetinib Palbociclib } \\
\text { Trifluridine and Tipiracil } \\
\text { Hydrochloride }\end{array}$ & 2 & $\begin{array}{c}\text { KRAS- and NRAS-mutant Metastatic } \\
\text { Colorectal Cancers }\end{array}$ \\
\hline NCT01933932 & $\begin{array}{c}\text { Selumetinib, Docetaxel, } \\
\text { Pegylated G-CSF }\end{array}$ & 3 & $\begin{array}{c}\text { KRAS Mutation-Positive Locally Advanced or } \\
\text { Metastatic NSCLC [97,121] }\end{array}$ \\
\hline
\end{tabular}

\section{Erk Inhibitors}

LY3214996 w/o Midazolam or Abemaciclib or Nab-paclitaxel

NCT02857270 or Gemcitabine or Encorafenib or Cetuximab
Metastatic Melanoma or NSCLC with B-Raf or RAS Mutations [122,123]

\begin{tabular}{|c|c|c|c|}
\hline NCT04305249 & AZD0364 & 1 & $\begin{array}{c}\text { Advanced Solid Tumors and Hematological } \\
\text { Malignancies with Alterations in the } \\
\text { RAS-MAPK Pathway }\end{array}$ \\
\hline NCT02972034 & MK-8353 and Pembrolizumab & 1 & Advanced Malignancies \\
\hline NCT03698994 & Ulixertinib & 2 & $\begin{array}{c}\text { Tumors Harboring Activating MAPK } \\
\text { Pathway Mutations }\end{array}$ \\
\hline \multicolumn{4}{|c|}{ Vertical Strategies } \\
\hline NCT04835805 & $\begin{array}{l}\text { Belvarafenib, Cobimetinib and } \\
\text { Atezolizumab }\end{array}$ & 1 & $\begin{array}{l}\text { NRAS-mutant Advanced Melanoma Who } \\
\text { Have Received Anti-PD-1/PD-L1 Therapy }\end{array}$ \\
\hline NCT03284502 & $\begin{array}{l}\text { Belvarafenib and Cobimetinib } \\
\text { or Cetuximab }\end{array}$ & 1 & $\begin{array}{l}\text { Locally advanced, or metastatic solid tumors } \\
\text { with RAS- or Raf-mutation }\end{array}$ \\
\hline NCT02974725 & $\begin{array}{l}\text { LXH254 and LTT462 or } \\
\text { Trametinib or Ribociclib }\end{array}$ & 1 & $\begin{array}{c}\text { Advanced or Metastatic KRAS- or } \\
\text { B-Raf-mutant NSCLC or } \\
\text { NRAS-mutant Melanoma }\end{array}$ \\
\hline NCT03905148 & Lifirafenib, Mirdametinib & $1 / 2$ & Advanced or Refractory Solid Tumors \\
\hline NCT04417621 & $\begin{array}{l}\text { LXH254, LTT462, Trametinib, } \\
\text { Ribociclib }\end{array}$ & 2 & $\begin{array}{l}\text { Previously Treated Unresectable or Metastatic } \\
\text { B-Raf }{ }^{V 00} \text { or NRAS-mutant Melanoma }\end{array}$ \\
\hline NCT04059224 & Trametinib, Dabrafenib & 2 & $\begin{array}{c}\text { Advanced pretreated BRAFV600 } \\
\text { wild-type/NRAS-mutant melanoma and } \\
\text { advanced pretreated BRAF V600 } \\
\text { wild-type/NRAS wild-type melanoma }\end{array}$ \\
\hline \multicolumn{4}{|c|}{ Metabolic Dependencies } \\
\hline NCT03825289 & $\begin{array}{l}\text { Trametinib and } \\
\text { Hydroxychloroquine }\end{array}$ & 1 & Metastatic Pancreatic Cancer \\
\hline NCT04145297 & $\begin{array}{l}\text { Ulixertinib and } \\
\text { Hydroxychloroquine }\end{array}$ & 1 & $\begin{array}{c}\text { Advanced MAPK-mutant } \\
\text { Gastrointestinal Adenocarcinomas }\end{array}$ \\
\hline NCT04132505 & $\begin{array}{l}\text { Binimetinib and } \\
\text { Hydroxychloroquine }\end{array}$ & 1 & KRAS-mutant Metastatic Pancreatic Cancer \\
\hline NCT04735068 & $\begin{array}{l}\text { Binimetinib and } \\
\text { Hydroxychloroquine pill }\end{array}$ & 2 & Advanced KRAS-mutant NSCLC \\
\hline
\end{tabular}




\subsection{Erk Inhibitors}

The final kinase component of the three-layered MAPK cascade, Erk, is another target to evade compensatory resistance mechanisms. Several ATP-competitive Erk1/2 inhibitors, including ASN007 [124], LY3214996 [125], GDC-0994 [126] and MK-8353 [127], have been discovered, and some of them demonstrated a significant anti-tumor activity in tumors bearing RAS mutations. However, the therapeutic index of Erk inhibitors remains limited in monotherapies due to their inhibitory role in both malignant and normal tissues. Instead, they have been generally explored in combined modality settings to potentiate their effectiveness in cancers with RAS mutations.

Ravoxertinib (GDC-0994) is an orally available small molecule targeting ERK1/2 kinase [128] with promising preclinical efficacy findings from both in vitro and in vivo experiments $[129,130]$. These findings have led to the progression of GDC-0994 through human clinical trials. Disappointingly, in a phase I clinical trial, GDC-0994 monotherapy has not provided a significant clinical benefit at tolerable doses in patients with KRAS mutations [131]. In another clinical study, the effect of the compound has been evaluated in combination with cobimetinib, however the phase I study was terminated early due to the intolerability of the combination with dose-limiting toxicities of myocardial infarction and rash (NCT02457793) [132]. LY3214996, which is a novel and highly selective small-molecule inhibitor of Erk1/2, has been shown to exhibit robust anti-tumor activity in xenograft models of RAS-mutant lung cancer when administered in an intermittent regimen [125]. Consistently, LY3214996 exhibited a well-tolerable and synergistic activity profile in xenograft models of KRAS-mutant NSCLC and colorectal cancer in combined modality settings $[133,134]$. On the basis of its preclinical efficacy and the rationale provided by the combinatorial studies, LY3214996 was advanced into human clinical trials in cancers with RAS mutations (NCT02857270). Another Erk1/2 inhibitor, ASN007, which is a potent and selective biomolecule with a long target residence time, showed promising anti-tumor activity in vitro. It impeded tumor growth in xenograft models with B-Raf and RAS mutations [135] and also synergized with PI3K inhibitors both in vitro and in vivo [124]. Given that ASN007, alone or in combination with other agents, is expected to provide a therapeutic option for RAS-mutant cancers, it has gone to human clinical trials (NCT03415126). However, data about clinical activity are not yet available. Ulixertinib (BVD-523) is another Erk1/2 inhibitor that has been shown to suppress tumor growth and induce tumor regression in B-Raf and RAS-mutant xenograft models [136-138]. In a phase I dose-escalation and expansion study, ulixertinib exhibited a tolerable safety profile with promising pharmacodynamic effects in NRAS- and B-Raf-mutant solid tumors (NCT01781429). Clinical studies are ongoing to examine its role in tumors harboring activating MAPK mutations as a single agent or in combination with other agents (NCT03698994, NCT04145297). Recently, the combination of AZD0364, a selective Erk1/2 inhibitor, and selumetinib has been shown to alleviate tumor progression in multiple xenograft models of KRAS-mutant NSCLC [139]. Similarly, Catalano et al. showed that dual inhibition of MEK and Erk represented anti-tumor efficacy and blocked the emergence of drug resistance in an HRAS ${ }^{\mathrm{G} 12 \mathrm{C}}$-driven autochthonous sarcoma model. However, this combination could not be successful to revert previously developed resistance, which offers the use of dual MEK and Erk treatment as a first-line therapy [140]. In addition to these, the authors noted that some cell lines resistant to combined MEK and Erk inhibition showed dependency on MAP4K4 activity, which serves MAP4K4 as a potential new therapeutic target [140]. Despite these successful examples of dual MEK and Erk inhibition in some RAS-mutant models, the potential of these combinations for clinical implementation awaits further investigation.

As another example of intra-pathway dual inhibition of the MAPK pathway, concurrent application of pan-Raf inhibitors and Erk inhibitors proved potent at low doses in cell line, organoid and rat models of PDAC with KRAS mutations [141]. Altogether, these data suggest that Erk inhibitor-anchored treatment strategies can be adopted as a therapeutic option in RAS-mutant settings. Clinical studies utilizing MK-8353 (NCT02972034), AZD0364 (NCT04305249) and LTT462 (NCT02974725) as monotherapy or in combination 
with other therapeutic agents are also ongoing to describe the response rate within patients with RAS mutations.

The functional activity of Erk requires its translocation to the nucleus. Cytosolic active Erk is phosphorylated by MEK on its specific regulatory residues and undergoes a conformational change that releases Erk from its anchoring proteins. Then, exposed Ser residue located within the nuclear translocation sequence (NTS) is phosphorylated, triggering the interaction of Erk and the beta-like importin, Imp7, thereby escorting Erk to the nucleus, where Erk activates a large number of targets [142,143]. In an effort to block Erk/Imp7 interaction, an NTS-derived phosphomimetic peptide (EPE) has been developed and shown to inhibit proliferation of RAS-mutant cancer cells without affecting immortalized cells [142]. In a later study, Arafeh et al. showed that concomitant inhibition of MEK and the nuclear translocation of Erk synergistically reduced the viability of some NRAS mutant melanomas [144]. These findings point to the therapeutic potential of targeting nuclear translocation of Erk1/2 for cancers with RAS-mutations.

Erk5 is a more recent member of the MAPK family, which is most similar to the Erk1/2 subfamily but reveals responses through distinct mechanisms [145]. A number of studies have reported the role of Erk5 in the lack of efficacy of MAPK inhibitors in melanomas harboring NRAS and B-Raf mutations [146-148]. Adam et al. have shown that inhibition of Erk5 effectively sensitized NRAS-mutant melanoma cells to MAPK inhibition. Dual targeting of MEK and Erk5 using Trametinib plus XMD8-92 inhibited the growth of NRASmutant melanoma cells and repressed tumor progression in NRAS-mutated melanoma xenografts [148]. Concomitant inhibition of MEK1/2 and Erk5 could offer enhanced clinical efficacy for anti-cancer therapies in patients with RAS mutations.

\section{PI3K-Akt Signaling Inhibitors and Vertical Strategies}

Aberrations in the PI3K-Akt signaling pathway have been implicated with tumorigenesis and resistance to anti-cancer therapies. Dysregulation of the PI3K signaling can occur through different mechanisms with a subset of mutations in the axis. These alterations include amplification of RTKs (EGFR and HER2), mutations in PI3K subunits (p110a, and p85a, encoded by PIK3CA and PIK3R1, respectively), loss/mutation of the phosphatase tensin homolog (PTEN), Akt overexpression or RAS hyperactivation. Singly targeting RAS-induced overactivation of PI3K-Akt signaling remains challenging due to the intrinsic resistance caused by beta catenin [149] and p90 ribosomal S6 kinase (RSK) activation $[150,151]$, the latter as a family of Erk substrate members. Thus, inhibitors of the components of PI3K-Akt signaling have been generally combined with different agents to exert a potent anti-cancer effect.

In the PI3K-Akt signaling, PI3K is the first and direct downstream kinase effector of RAS as a potential drug target. Two major classes of PI3K inhibitors, including isoformselective inhibitors and pan-PI3K inhibitors, have been developed to antagonize PI3K-Akt signaling. In 2019, the PIK3CA inhibitor BYL719 (Alpelisib, Novartis) was approved by the FDA for the treatment of estrogen receptor-positive (ER+) breast cancer patients with PIK3CA mutations [152]. Studies evaluating the therapeutic efficacy of BYL219 in cancers bearing RAS mutations are under ongoing investigations [153,154]. The latter type of PI3K inhibitors, pan-PI3K inhibitors, include buparlisib (BKM120), PX-866, copanlisib (BAY80), LY294002, pilaralisib (XL147), pictilisib (GDC-0941) and taselisib (GDC-0032). In a recent study, GDC-0941 and siRNA therapeutics targeting KRAS (siKRAS) have been combined to test their synergistic anti-tumor effect in ovarian cancer cell lines and in an allograft ovarian cancer model harboring KRAS mutations. Here, the simultaneous use of GDC-0941 and siKRAS co-inhibited PI3K and RAS and led to the induction of apoptosis in the animal model [155]. There have been multiple examples of clinical trials for the use of siRNAs in targeted therapies [156], yet their potential for clinical utility remains to be investigated in RAS-mutant cancers.

The second kinase member in the PI3K-mTOR axis, Akt, consists of three functionally distinct isoforms, including Akt-1, Akt-2 and Akt-3. It has been shown that RAS-induced 
oncogenic signals are mainly relayed through the Akt-1 isoform in KRAS-mutant lung tumors [157]. In contrast, Akt-1 inhibition induced migration and invasion in KRAS or EGFR mutant NSCLC cells, but not in KRAS/EGFR wild-type cells [158]. Considering that differential genetic background contributes to the controversial roles of Akt in cancer, the selection of patient groups for clinical trials of Akt inhibitors is of great importance to avoid an Akt-inhibition-mediated metastatic effect. Recently, inhibition of Akt- 1 has been shown to induce metastasis through EGFR-mediated $\beta$-catenin nuclear accumulation in breast cancer cells, suggesting that the concomitant inhibition of Akt-1 and EGFR might be effective to limit the metastatic potential of Akt-1 inhibition [159]. It has been shown that one of the compensatory cellular mechanisms of KRAS-mutant colorectal cancer cells is the increased phosphorylation of RTKs upon Akt inhibition [160]. In this study, the combinatorial use of an allosteric Akt inhibitor (MK-2206) and different RTK inhibitors (Lapatinib, OSI-906, jnj38877605) reduced the growth of cancer cells harboring KRAS mutations. Similarly, on the basis of the finding that FGFR signaling is overactivated in advanced prostate cancer, the combined use of AZD4547 (FGFR receptor kinase inhibitor) and AZD5363 (Akt inhibitor) has led to a reduction in the proliferation of prostate cancer cells both in vitro and in vivo [161]. Given these encouraging preclinical findings, combinations of Akt and RTK inhibitors await testing in clinical trials of RAS-mutant cancer therapy.

Inhibitors targeting mTOR, one of the downstream effectors of RAS, have been clinically tested, however the majority of single-agent therapies targeting mTOR did not result in clear clinical benefits. Inhibition of mTOR has been shown to stimulate feedback activation mechanisms including MEK/Erk or Akt signaling, demanding for combinatorial treatment regimens [162,163]. A phase 1 trial is currently ongoing based on the combination of a dual Raf/MEK inhibitor and evorilumus (mTOR inhibitor) (NCT02407509) in patients with RAS/Raf-mutant solid tumors. Another strategy might be to concomitantly target mTOR with other cancer-specific dependencies. For example, the abnormal activity of histone deacetylases (HDACs), which are critical regulators of gene expression, has been associated with key oncogenic events [164]. In this regard, Malone et al. analyzed the effect of dual inhibition of HDAC and mTOR in KRAS-mutant NSCLC and showed that this combination triggered catastrophic oxidative stress and tumor regression in RAS-driven tumors [165]. In several cancer types, WEE1, which is the gatekeeper of the G2 arrest, is expressed at high levels, and its inhibition sensitizes cancer cells to DNA-damaging agents by compromising the G2-M checkpoint [166]. Owing to this, Hai et al. have shown that the combined inhibition of WEE1 and mTOR synergistically induced cytotoxicity in KRAS-mutated NSCLC cells and delayed tumor growth in xenograft models without any drug-related toxicity [167]. Together, these findings represent some tractable vulnerabilities of RAS-driven cancers and are expected to bring further benefit in the context of drug combinations. More promisingly, two independent studies have shown that the efficacy of the KRAS ${ }^{\mathrm{G} 12 \mathrm{C}}$ inhibitor ARS-1620 was increased when combined with mTOR and an IGF1R inhibitor [15] and PI3K inhibitor [14] in lung cancer cells and in vivo models. These results showed that inhibiting the PI3K-mTOR pathway would potentiate the effectiveness of KRAS ${ }^{\mathrm{G} 12 \mathrm{C}}$ covalent inhibitors and provide a therapeutic opportunity for patients with KRAS ${ }^{\mathrm{G} 12 \mathrm{C}}$ mutations in combined settings.

\section{Horizontal Strategies Targeting Both RAS Effector Pathways}

Owing to the adaptive resistance to selective targeting of MAPK signaling in RASmutant cancers, the PI3K-mTOR pathway has attracted growing interest by virtue of its complementarity to the MAPK pathway. Not only do these pathways share common inputs but also they can both be activated by oncogenic RAS and appear to provide some compensatory signaling when one or the other is inhibited (Figure 2). The therapeutic index of inhibitors targeting a single component is limited by this crosstalk, which provides numerous possibilities for overcoming the effects of inhibition. Horizontally targeting multiple effector arms might be effective to increase the therapeutic potential of inhibitors [36]. Since preclinical studies demonstrated that dual inhibition of MEK and 


\begin{abstract}
Akt can abolish RAS signaling [168,169], selumetinib and MK-2206 have been combined to evaluate drug toxicities and anti-tumor activity in patients with KRAS mutations. Patients revealed significant treatment benefits at pulsatile dosing, which mitigate toxicities [170]. In line with this finding, it has been previously reported that different dosing regimens might change anti-tumor activity and off-target toxicities, particularly in combined modality settings which suffer from adverse effects [171]. Disappointingly, in a phase I trial, combining MEK and PI3K inhibitors have failed to determine the maximally tolerated dose due to a high incidence of adverse effects in patients with KRAS, NRAS, B-Raf or PIK3CA mutations, whereas they have shown synergistic pharmacodynamic tumor activity (NCT01392521) [172]. On the other side, blockade of RAS downstream effectors in conjunction with other cellular targets involved in RAS-driven cancers may also reveal a powerful punch. For example, Ischenko et al. showed that targeting histone deacetylases (HDACs) in combination with MEK and PI3K induced apoptosis and prevented the development of lung metastases in vivo [173]. Another drug trio, targeting MEK (PD-901), CDK4/6 (palbociclib) and mTORC1/2 (AZD2014), has reduced colony formation and S6 phosphorylation in MEKi/CDK4/6i-resistant melanoma, and significantly induced apoptosis in NRAS-mutant melanoma, but it is of note that the treatment success might be hindered by increased toxicities [174].
\end{abstract}

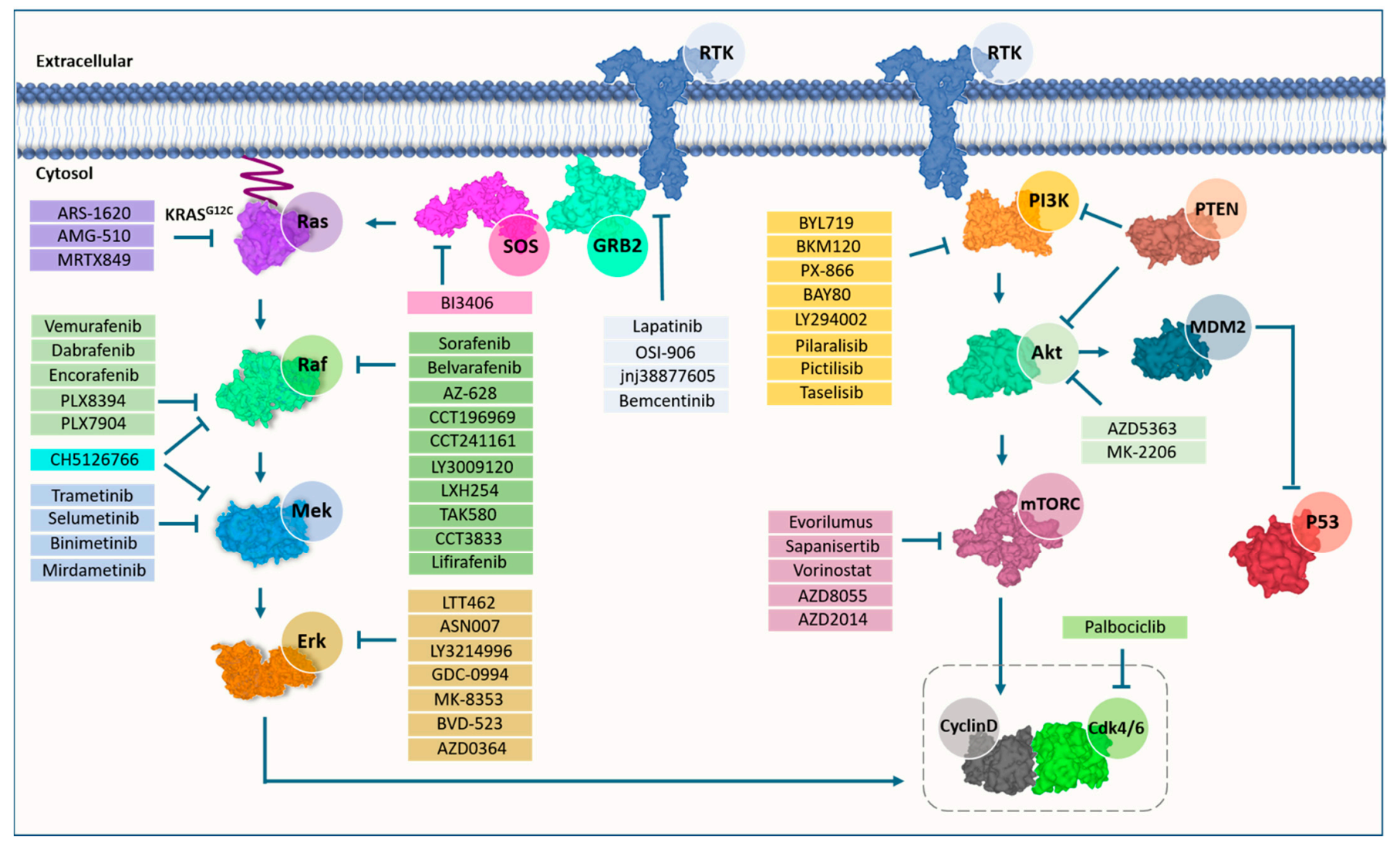

Figure 2. Inhibitors targeting rat sarcoma virus (RAS) effector pathways.

Tumor radio-resistance remains a major obstacle for the treatment of many types of cancer. Both MAPK and PI3K-mTOR pathways have been implicated with radioresistance of RAS-dependent cancer cells $[175,176]$. Clinical data show that most cancer patients bearing KRAS mutations have a higher frequency of metastasis and recurrence of disease following radiotherapy [177]. Activation of the PI3K-Akt pathway has been shown to enable the repair of double-stranded breaks formed by radiotherapy through the induction of DNA-PKcs in cancer cells [178-180]. Akt-1 directly binds to DNA-PKcs and promotes its activity to initiate the NHEJ repair pathway, thereby resulting in the resistance to radiotherapy. Further, it has been shown that PI3K inhibition stimulates 
MEK/Erk-dependent reactivation of Akt, thus targeting PI3K alone most likely will not be sufficient to sensitize KRAS-mutant NSCLC cells to irradiation. Correspondingly, dual targeting of PI3K and MEK efficiently improved radio-sensitization through the blockade of Akt reactivation and impairment of DSBs repair [181]. In a phase $\mathrm{Ib}$ dose-escalation study, a highly selective pan-PI3K inhibitor, buparlisib, in combination with the MEK1/2 inhibitor trametinib, represented promising anti-tumor activity in patients with KRASmutant ovarian cancer; however, it should be noted that the combination required dose modifications and interruptions due to the toxicity [182].

Recently, research has focused intensively on Erk inhibitor-based drug combinations, which seem more attractive due to their ability to mitigate feedback relief. Dual inhibition of Erk and PI3K/mTOR with LY3214996 and LY3023414 inhibitors respectively, has been tolerable and resulted in synergistic inhibition on tumor growth in RAS-driven lung cancer [125]. We await future clinical trials to understand the efficacy of this combination in terms of therapeutic limitations. A novel bioactive compound containing a benzothiophene nucleus, DPS2, has been reported to show a potent anti-tumor effect in several colorectal cancer and melanoma cell lines harboring B-Raf or KRAS alterations. DPS2 has shown dual inhibitory action toward Erk and Akt phosphorylation in preclinical models [183]. In cancer cells, DPS2 has been shown to drive apoptosis and also reduce autophagy with high selectivity [183].

A great majority of recent combinatorial strategies targeting MAPK and PI3K/Akt signaling together have been found to be poorly tolerated in clinical studies involving patients with RAS mutations, which diverted the attention to other cellular targets. The inhibition of HSP90, highly expressed in most cancers, in combination with a MEK inhibitor has been identified as a promising therapeutic strategy for KRAS-mutant NSCLC. Several clinical trials have been conducted to examine the effect of AUY922, an HSP90 inhibitor, on solid tumors, and revealed the low cellular toxicity of the agent $[184,185]$. Owing to the fact that the clinical efficacy of AUY922 remains poor in monotherapies, it has been synergized with trametinib in KRAS-mutant NSCLC and represented a potent anti-tumor activity both in vitro and in vivo [186]. In a later study, the same group has shown that the HSP90 inhibitor, AUY922, suppressed both PI3K/mTOR and Raf/MEK/Erk axes and sensitized cells to PI3K inhibition [187]. In contrast to the combination of MEK and PI3K inhibitors, dual inhibition of HSP90 and PI3K did not induce toxicity in normal cells. Furthermore, AUY922 in combination with the PI3K/mTOR dual inhibitor GSK458 induced apoptosis and reduced compensatory pathway activation in KRAS-mutant NSCLC [187]. Further clinical trials are required to evaluate the efficacy and tolerability of these combinations in patients with RAS mutations. Of note, due to the direct association of HSP90 with specific components of both RAS effector pathways, HSP90-anchored combinations are discussed within the current section.

\section{Targeting Metabolic Dependencies in Combination with RAS Effectors}

One of the key hallmarks of cancer is the metabolic reprogramming of tumor cells, which meet the need of increased biomass by altering their metabolism to grow [188]. RAS signaling promotes metabolic adaptation of tumor cells by coordinating different anabolic processes, including lipid, nucleotide and glycolytic pathways. A growing body of evidence has shown that RAS-driven tumors develop metabolic dependency owing to autophagy to generate metabolic substrates for tumor maintenance [189]. Thus, co-targeting RAS-downstream effectors and the autophagic reliance of the cancerous cells might be an effective strategy to improve tumor response to treatment. Chloroquine and hydroxychloroquine are well-characterized autophagy inhibitors, which function by inhibiting lysosomal acidification. Combinations of autophagy inhibitors with MEK (trametinib and MEK162) [190,191] or Erk (SCH772984) [192] inhibitors or genetic MAPK inhibition [193] have been shown to result in synergistic anti-proliferative effects against multiple refractory RAS-mutant cancer models, including pancreatic, melanoma and lung cancers. These results encouraged the initiation of a number of ongoing clinical trials combining hydroxy- 
chloroquine with trametinib (NCT03825289), binimetinib (NCT04132505, NCT04735068) and ulixertinib (NCT04145297) in RAS-addicted cancers, but data about clinical efficacy are not yet available. Although there are some promising results to treat RAS-driven cancers with several combinations, autophagy inhibitors have low potency and require a longer time for efficient treatment. Thus, more potent autophagy inhibitors are currently under development. Given that certain cancer genotypes may be particularly susceptible to autophagy inhibition, challenges and opportunities remain in the selection of patients most likely to benefit from this strategy.

One of the most important metabolisms related to cancer is the mevalonate pathway, which is an essential metabolic pathway for cholesterol biosynthesis. Tumorigenesis requires increased mevalonate pathway flux to meet the need for precursors. The mevalonate synthesis inhibitors, Statins, suppress protein prenylation and mediate several cellular events associated with cancer hallmarks, including proliferation, survival and metastasis. Statins have been previously shown to induce apoptosis by suppressing Erk and Akt activation [194]. Blockade of the mevalonate pathway with the oral administration of statins has been reported as a promising strategy when combined with MEK inhibitors (trametinib and $\mathrm{CH} 5126766$ ) against Akt activation related to MEK inhibitor resistance [195]. On the other hand, it has been shown that inhibition of autophagy sensitizes KRAS-mutant colorectal cancer cells to concurrent use of glycolysis and mevalonate pathway inhibitors [196], suggesting that multiple metabolisms may be targeted simultaneously. The use of kinase inhibitors in alternative drug duos or trios is awaiting evaluation for targeting metabolic dependencies of cancer cells in combination with RAS effectors.

\section{Summary and Perspectives}

Tremendous progress has been made in understanding the genetic architecture, the biological heterogeneity and the distinct molecular pathways driven by RAS oncogenes. Although none of these findings could be successfully extrapolated into cancer therapy yet, future progress will be built on the foundation of this deeper understanding of tumor response. The more detailed assessment of these finely balanced signaling networks could help researchers refine their approach and allow greater focus on rational drug combinations. These observations underscore that a focus should be placed on in-depth optimization of timing, dosing schedules and treatment sequences to remedy toxicities and side effects of drugs. Evidently, there is also still a need to improve clinical tools for accurately stratifying patients based on their molecular status. In this regard, the specific markers associated with drug sensitivity and acquired resistance in aiding therapeutic interventions for RAS-driven cancer entities are of utmost importance.

Beyond small-molecule inhibitors, some innovative therapeutic approaches, such as oncolytic virus-mediated gene-editing [197], mRNA vaccines [198] and novel classes of inhibitors [199], have emerged. RAS-driven tumors have been shown to possess a natural vulnerability to the oncolytic M1 virus, which provides insights into the use of gene-editing oncolytic virotherapy in cancers bearing RAS mutations [200]. Oncolytic viruses are currently under examination and might be a promising alternative for RAS-driven cancer therapy in the upcoming years [201,202]. On the other hand, proteolysis-targeting chimera (PROTAC), comprising ligands of target proteins, E3 ligase-recruiting elements and linkers, has been shown as a potential anticancer therapeutic in KRAS-mutant cancers $[203,204]$. In addition to these, mRNA vaccines that induce an immune response against specific tumor antigens have been found to be promising in checkpoint-inhibitor-treated melanoma [205]. A phase 1 clinical trial is currently ongoing with a tetravalent RNA-lipoplex cancer vaccine targeting four melanoma-associated antigens in advanced melanoma patients (NCT02410733). There are also improvements in conventional therapies, e.g., stereotactic ablative radiotherapy (SBRT) has been found to be significantly efficient in various solid tumors with remarkable advantages over conventional radiotherapy, and its use in combined modality settings is now considered in various strategies [206]. 
In the near future, all these efforts will likely bear fruit for the treatment of RAS-driven cancers. Each strategy developed on the basis of scientific research will form another pillar for cancer treatment and serve as an opportunity to develop efficient and well-tolerated combinations in clinical practice.

Supplementary Materials: The following is available online. Table S1: Inhibitors and their chemical structures along with their potency.

Author Contributions: Conceptualization, O.T. and G.D.D.; writing-original draft preparation, O.T. writing-review and editing, G.D.D. All authors have read and agreed to the published version of the manuscript.

Funding: This work was supported by The Scientific and Technological Research Council of Turkey (TUBITAK) (117Z848).

Institutional Review Board Statement: Not applicable.

Informed Consent Statement: Not applicable.

Conflicts of Interest: The authors declare no conflict of interest.

\section{References}

1. Bos, J.L.; Rehmann, H.; Wittinghofer, A. GEFs and GAPs: Critical Elements in the Control of Small G Proteins. Cell 2007, 129, 865-877. [CrossRef]

2. Catalogue of Somatic Mutations in Cancer. Available online: https:/ / cancer.sanger.ac.uk/cosmic (accessed on 15 May 2021).

3. Fernández-Medarde, A.; Santos, E. Ras in cancer and developmental diseases. Genes Cancer 2011, 2, 344-358. [CrossRef] [PubMed]

4. Riely, G.J.; Marks, J.; Pao, W. KRAS mutations in non-small cell lung cancer. Proc. Am. Thorac. Soc. 2009, 6, 201-205. [CrossRef] [PubMed]

5. Prior, I.A.; Lewis, P.D.; Mattos, C. A comprehensive survey of ras mutations in cancer. Cancer Res. 2012, 72, 2457-2467. [CrossRef]

6. Govindan, R.; Fakih, M.G.; Price, T.J.; Falchook, G.S.; Desai, J.; Kuo, J.C.; Strickler, J.H.; Krauss, J.C.; Li, B.T.; Denlinger, C.S.; et al. Phase I study of AMG 510, a novel molecule targeting KRAS G12C mutant solid tumours. Ann. Oncol. 2019, 30, v163-v164. [CrossRef]

7. Kessler, D.; Gmachl, M.; Mantoulidis, A.; Martin, L.J.; Zoephel, A.; Mayer, M.; Gollner, A.; Covini, D.; Fischer, S.; Gerstberger, T.; et al. Drugging an undruggable pocket on KRAS. Proc. Natl. Acad. Sci. USA 2019, 116, 15823-15829. [CrossRef]

8. Mullard, A. Cracking KRAS. Nat. Rev. Drug Discov. 2019, 18, 887-892. [CrossRef]

9. Canon, J.; Rex, K.; Saiki, A.Y.; Mohr, C.; Cooke, K.; Bagal, D.; Gaida, K.; Holt, T.; Knutson, C.G.; Koppada, N.; et al. The clinical KRAS(G12C) inhibitor AMG 510 drives anti-tumour immunity. Nature 2019, 575, 217-223. [CrossRef] [PubMed]

10. Hallin, J.; Engstrom, L.D.; Hargi, L.; Calinisan, A.; Aranda, R.; Briere, D.M.; Sudhakar, N.; Bowcut, V.; Baer, B.R.; Ballard, J.A.; et al. The KRASG12C inhibitor MRTX849 provides insight toward therapeutic susceptibility of KRAS-mutant cancers in mouse models and patients. Cancer Discov. 2020, 10, 54-71. [CrossRef]

11. Kim, D.; Xue, J.Y.; Lito, P. Targeting KRAS(G12C): From Inhibitory Mechanism to Modulation of Antitumor Effects in Patients. Cell 2020, 183, 850-859. [CrossRef]

12. Janes, M.R.; Zhang, J.; Li, L.S.; Hansen, R.; Peters, U.; Guo, X.; Chen, Y.; Babbar, A.; Firdaus, S.J.; Darjania, L.; et al. Targeting KRAS Mutant Cancers with a Covalent G12C-Specific Inhibitor. Cell 2018, 172, 578-589.e17. [CrossRef]

13. Ostrem, J.M.; Peters, U.; Sos, M.L.; Wells, J.A.; Shokat, K.M. K-Ras(G12C) inhibitors allosterically control GTP affinity and effector interactions. Nature 2013, 503, 548-551. [CrossRef]

14. Misale, S.; Fatherree, J.P.; Cortez, E.; Li, C.; Bilton, S.; Timonina, D.; Myers, D.T.; Lee, D.; Gomez-Caraballo, M.; Greenberg, M.; et al. KRAS G12C NSCLC models are sensitive to direct targeting of KRAS in combination with PI3K inhibition. Clin. Cancer Res. 2019, 25, 796-807. [CrossRef]

15. Molina-Arcas, M.; Moore, C.; Rana, S.; Van Maldegem, F.; Mugarza, E.; Romero-Clavijo, P.; Herbert, E.; Horswell, S.; Li, L.S.; Janes, M.R.; et al. Development of combination therapies to maximize the impact of KRAS-G12C inhibitors in lung cancer. Sci. Transl. Med. 2019, 11, 7999. [CrossRef]

16. Papke, B.; Der, C.J. Drugging RAS: Know the enemy. Science 2017, 355, 1158-1163. [CrossRef] [PubMed]

17. Wang, W.; Yuan, T.; Qian, M.; Yan, F.; Yang, L.; He, Q.; Yang, B.; Lu, J.; Zhu, H. Post-translational modification of KRAS: Potential targets for cancer therapy. Acta Pharmacol. Sin. 2020, 42, 1201-1211. [CrossRef]

18. Henkels, K.M.; Rehl, K.M.; Cho, K. Blocking K-Ras Interaction With the Plasma Membrane Is a Tractable Therapeutic Approach to Inhibit Oncogenic K-Ras Activity. Front. Mol. Biosci. 2021, 8. [CrossRef] [PubMed]

19. Macdonald, J.S.; McCoy, S.; Whitehead, R.P.; Iqbal, S.; Wade, J.L., III; Giguere, J.K.; Abbruzzese, J.L. A phase II study of farnesyl transferase inhibitor R115777 in pancreatic cancer: A Southwest oncology group (SWOG 9924) study. Investig. New Drugs 2005, 23, 485-487. [CrossRef] [PubMed]

20. Johnston, S.R.D. Farnesyl transferase inhibitors: A novel targeted therapy for cancer. Lancet Oncol. 2001, 2, 18-26. [CrossRef] 
21. Konstantinopoulos, P.A.; Karamouzis, M.V.; Papavassiliou, A.G. Post-translational modifications and regulation of the RAS superfamily of GTPases as anticancer targets. Nat. Rev. Drug Discov. 2007, 6, 541-555. [CrossRef]

22. Aguirre, A.J.; Hahn, W.C. Synthetic Lethal Vulnerabilities in KRAS-Mutant Cancers. Cold Spring Harb. Perspect. Med. 2018, 8. [CrossRef]

23. De Luca, A.; Maiello, M.R.; D'Alessio, A.; Pergameno, M.; Normanno, N. The RAS/RAF/MEK/ERK and the PI3K/AKT signalling pathways: Role in cancer pathogenesis and implications for therapeutic approaches. Expert Opin. Ther. Targets 2012, 16, S17-S27. [CrossRef] [PubMed]

24. Bishop, W.R.; Kirschmeier, P.; Baum, C. Farnesyl transferase inhibitors: Mechanism of action, translational studies and clinical evaluation. Cancer Biol. Ther. 2003, 2, 95-103. [CrossRef]

25. McCubrey, J.A.; Steelman, L.S.; Abrams, S.L.; Lee, J.T.; Chang, F.; Bertrand, F.E.; Navolanic, P.M.; Terrian, D.M.; Franklin, R.A.; D'Assoro, A.B.; et al. Roles of the RAF/MEK/ERK and PI3K/PTEN/AKT pathways in malignant transformation and drug resistance. Adv. Enzym. Regul. 2006, 46, 249-279. [CrossRef]

26. Wellbrock, C.; Karasarides, M.; Marais, R. The RAF proteins take centre stage. Nat. Rev. Mol. Cell Biol. 2004, 5, 875-885. [CrossRef] [PubMed]

27. Dhillon, A.S.; Meikle, S.; Yazici, Z.; Eulitz, M.; Kolch, W. Regulation of Raf-1 activation and signalling by dephosphorylation. EMBO J. 2002, 21, 64-71. [CrossRef] [PubMed]

28. Kholodenko, B.N.; Hancock, J.F.; Kolch, W. Signalling ballet in space and time. Nat. Rev. Mol. Cell Biol. 2010, 11, 414-426. [CrossRef]

29. Lake, D.; Corrêa, S.A.L.; Müller, J. Negative feedback regulation of the ERK1/2 MAPK pathway. Cell. Mol. Life Sci. 2016, 73, 4397-4413. [CrossRef]

30. Yao, Z.; Torres, N.M.; Tao, A.; Gao, Y.; Luo, L.; Li, Q.; de Stanchina, E.; Abdel-Wahab, O.; Solit, D.B.; Poulikakos, P.I.; et al. BRAF Mutants Evade ERK-Dependent Feedback by Different Mechanisms that Determine Their Sensitivity to Pharmacologic Inhibition. Cancer Cell 2015, 28, 370-383. [CrossRef]

31. Karoulia, Z.; Wu, Y.; Ahmed, T.A.; Xin, Q.; Bollard, J.; Krepler, C.; Wu, X.; Zhang, C.; Bollag, G.; Herlyn, M.; et al. An Integrated Model of RAF Inhibitor Action Predicts Inhibitor Activity against Oncogenic BRAF Signaling. Cancer Cell 2016, 30, 485-498. [CrossRef]

32. Yuan, T.L.; Cantley, L.C. PI3K pathway alterations in cancer: Variations on a theme. Oncogene 2008, 27, 5497-5510. [CrossRef] [PubMed]

33. Sengupta, S.; Peterson, T.R.; Sabatini, D.M. Regulation of the mTOR Complex 1 Pathway by Nutrients, Growth Factors, and Stress. Mol. Cell 2010, 40, 310-322. [CrossRef]

34. Xu, F.; Na, L.X.; Li, Y.F.; Chen, L.J. Roles of the PI3K/AKT/mTOR signalling pathways in neurodegenerative diseases and tumours. Cell Biosci. 2020, 10, 54. [CrossRef]

35. Castellano, E.; Downward, J. Role of RAS in the regulation of PI 3-kinase. Curr. Top. Microbiol. Immunol. 2010, 346, 143-169.

36. Mendoza, M.C.; Er, E.E.; Blenis, J. The Ras-ERK and PI3K-mTOR pathways: Cross-talk and compensation. Trends Biochem. Sci. 2011, 36, 320-328. [CrossRef]

37. Aksamitiene, E.; Kiyatkin, A.; Kholodenko, B.N. Cross-talk between mitogenic Ras/MAPK and survival PI3K/Akt pathways: A fine balance. Biochem. Soc. Trans. 2012, 40, 139-146. [CrossRef] [PubMed]

38. Fruman, D.A.; Rommel, C. PI3K and cancer: Lessons, challenges and opportunities. Nat. Rev. Drug Discov. 2014, 13, 140-156. [CrossRef]

39. Sos, M.L.; Fischer, S.; Ullrich, R.; Peifer, M.; Heuckmann, J.M.; Koker, M.; Heynck, S.; Stückrath, I.; Weiss, J.; Fischer, F.; et al. Identifying genotype-dependent efficacy of single and combined PI3K- and MAPK-pathway inhibition in cancer. Proc. Natl. Acad. Sci. USA 2009, 106, 18351-18356. [CrossRef]

40. Villanueva, J.; Infante, J.R.; Krepler, C.; Reyes-Uribe, P.; Samanta, M.; Chen, H.Y.; Li, B.; Swoboda, R.K.; Wilson, M.; Vultur, A.; et al. Concurrent MEK2 Mutation and BRAF Amplification Confer Resistance to BRAF and MEK Inhibitors in Melanoma. Cell Rep. 2013, 4, 1090-1099. [CrossRef] [PubMed]

41. Chapman, P.B.; Hauschild, A.; Robert, C.; Haanen, J.B.; Ascierto, P.; Larkin, J.; Dummer, R.; Garbe, C.; Testori, A.; Maio, M.; et al. Improved Survival with Vemurafenib in Melanoma with BRAF V600E Mutation. N. Engl. J. Med. 2011, 364, 2507-2516. [CrossRef] [PubMed]

42. Sosman, J.A.; Kim, K.B.; Schuchter, L.; Gonzalez, R.; Pavlick, A.C.; Weber, J.S.; McArthur, G.A.; Hutson, T.E.; Moschos, S.J.; Flaherty, K.T.; et al. Survival in BRAF V600-Mutant Advanced Melanoma Treated with Vemurafenib. N. Engl. J. Med. 2012, 366, 707-714. [CrossRef]

43. Hauschild, A.; Grob, J.J.; Demidov, L.V.; Jouary, T.; Gutzmer, R.; Millward, M.; Rutkowski, P.; Blank, C.U.; Miller, W.H.; Kaempgen, E.; et al. Dabrafenib in BRAF-mutated metastatic melanoma: A multicentre, open-label, phase 3 randomised controlled trial. Lancet 2012, 380, 358-365. [CrossRef]

44. Long, G.V.; Weber, J.S.; Infante, J.R.; Kim, K.B.; Daud, A.; Gonzalez, R.; Sosman, J.A.; Hamid, O.; Schuchter, L.; Cebon, J.; et al. Overall survival and durable responses in patients with BRAF V600-mutant metastatic melanoma receiving dabrafenib combined with trametinib. J. Clin. Oncol. 2016, 34, 871-878. [CrossRef]

45. Dummer, R.; Ascierto, P.A.; Gogas, H.J.; Arance, A.; Mandala, M.; Liszkay, G.; Garbe, C.; Schadendorf, D.; Krajsova, I.; Gutzmer, R.; et al. Encorafenib plus binimetinib versus vemurafenib or encorafenib in patients with BRAF-mutant melanoma (COLUMBUS): A multicentre, open-label, randomised phase 3 trial. Lancet Oncol. 2018, 19, 603-615. [CrossRef] 
46. Yang, H.; Higgins, B.; Kolinsky, K.; Packman, K.; Go, Z.; Iyer, R.; Kolis, S.; Zhao, S.; Lee, R.; Grippo, J.F.; et al. RG7204 (PLX4032), a selective BRAFV600E inhibitor, displays potent antitumor activity in preclinical melanoma models. Cancer Res. 2010, 70, 5518-5527. [CrossRef]

47. King, A.J.; Arnone, M.R.; Bleam, M.R.; Moss, K.G.; Yang, J.; Fedorowicz, K.E.; Smitheman, K.N.; Erhardt, J.A.; Hughes-Earle, A.; Kane-Carson, L.S.; et al. Dabrafenib; Preclinical Characterization, Increased Efficacy when Combined with Trametinib, while BRAF/MEK Tool Combination Reduced Skin Lesions. PLoS ONE 2013, 8, e67583. [CrossRef] [PubMed]

48. Koelblinger, P.; Thuerigen, O.; Dummer, R. Development of encorafenib for BRAF-mutated advanced melanoma. Curr. Opin. Oncol. 2018, 30, 125-133. [CrossRef] [PubMed]

49. Poulikakos, P.I.; Zhang, C.; Bollag, G.; Shokat, K.M.; Rosen, N. RAF inhibitors transactivate RAF dimers and ERK signalling in cells with wild-type BRAF. Nature 2010, 464, 427-430. [CrossRef]

50. Heidorn, S.J.; Milagre, C.; Whittaker, S.; Nourry, A.; Niculescu-Duvas, I.; Dhomen, N.; Hussain, J.; Reis-Filho, J.S.; Springer, C.J.; Pritchard, C.; et al. Kinase-Dead BRAF and Oncogenic RAS Cooperate to Drive Tumor Progression through CRAF. Cell 2010, 140, 209-221. [CrossRef]

51. Holderfield, M.; Deuker, M.M.; McCormick, F.; McMahon, M. Targeting RAF kinases for cancer therapy: BRAF-mutated melanoma and beyond. Nat. Rev. Cancer 2014, 14, 455-467. [CrossRef]

52. Su, F.; Viros, A.; Milagre, C.; Trunzer, K.; Bollag, G.; Spleiss, O.; Reis-Filho, J.S.; Kong, X.; Koya, R.C.; Flaherty, K.T.; et al. RAS Mutations in Cutaneous Squamous-Cell Carcinomas in Patients Treated with BRAF Inhibitors. N. Engl. J. Med. 2012, 366, 207-215. [CrossRef]

53. Peng, L.; Wang, Y.; Hong, Y.; Ye, X.; Shi, P.; Zhang, J.; Zhao, Q. Incidence and relative risk of cutaneous squamous cell carcinoma with single-agent BRAF inhibitor and dual BRAF/MEK inhibitors in cancer patients: A meta-analysis. Oncotarget 2017, 8, 83280-83291. [CrossRef]

54. Peng, S.B.; Henry, J.R.; Kaufman, M.D.; Lu, W.P.; Smith, B.D.; Vogeti, S.; Rutkoski, T.J.; Wise, S.; Chun, L.; Zhang, Y.; et al. Inhibition of RAF Isoforms and Active Dimers by LY3009120 Leads to Anti-tumor Activities in RAS or BRAF Mutant Cancers. Cancer Cell 2015, 28, 384-398. [CrossRef]

55. Sun, Y.; Alberta, J.A.; Pilarz, C.; Calligaris, D.; Chadwick, E.J.; Ramkissoon, S.H.; Ramkissoon, L.A.; Garcia, V.M.; Mazzola, E.; Goumnerova, L.; et al. A brain-penetrant RAF dimer antagonist for the noncanonical BRAF oncoprotein of pediatric low-grade astrocytomas. Neuro-Oncol. 2017, 19, 774-785. [CrossRef]

56. Cook, F.A.; Cook, S.J. Inhibition of RAF dimers: It takes two to tango. Biochem. Soc. Trans. 2021, 49, 237-251. [CrossRef]

57. Tang, Z.; Yuan, X.; Du, R.; Cheung, S.H.; Zhang, G.; Wei, J.; Zhao, Y.; Feng, Y.; Peng, H.; Zhang, Y.; et al. BGB-283, a novel RAF kinase and EGFR inhibitor, displays potent antitumor activity in BRAF-mutated colorectal cancers. Mol. Cancer Ther. 2015, 14, 2187-2197. [CrossRef] [PubMed]

58. Saturno, G.; Lopes, F.; Girotti, M.R.; Niculescu-Duvaz, I.; Niculescu-Duvaz, D.; Zambon, A.; Davies, L.; Johnson, L.; Preece, N.; Viros, A.; et al. Therapeutic efficacy of the paradox-breaking panRAF and SRC drug CCT3833/BAL3833 in KRAS-driven cancer models. Eur. J. Cancer 2016, 61, S199. [CrossRef]

59. Tambe, M.; Karjalainen, E.; Vähä-Koskela, M.; Bulanova, D.; Gjertsen, B.T.; Kontro, M.; Porkka, K.; Heckman, C.A.; Wennerberg, K. Pan-RAF inhibition induces apoptosis in acute myeloid leukemia cells and synergizes with BCL2 inhibition. Leukemia 2020, 34, 3186-3196. [CrossRef] [PubMed]

60. Vakana, E.; Pratt, S.; Blosser, W.; Dowless, M.; Simpson, N.; Yuan, X.J.; Jaken, S.; Manro, J.; Stephens, J.; Zhang, Y.; et al. LY3009120, a panRAF inhibitor, has significant anti-tumor activity in BRAF and KRAS mutant preclinical models of colo-rectal cancer. Oncotarget 2017, 8, 9251-9266. [CrossRef] [PubMed]

61. Müller, E.; Bauer, S.; Stühmer, T.; Mottok, A.; Scholz, C.J.; Steinbrunn, T.; Brünnert, D.; Brandl, A.; Schraud, H.; Kreßmann, S.; et al. Pan-Raf co-operates with PI3K-dependent signalling and critically contributes to myeloma cell survival inde-pendently of mutated RAS. Leukemia 2017, 31, 922-933. [CrossRef]

62. Suzuki, R.; Kitamura, Y.; Nakamura, Y.; Akashi, H.; Ogawa, Y.; Kawada, H.; Ando, K. Anti-tumor activities of the new oral pan-RAF inhibitor, TAK-580, used as monotherapy or in combination with novel agents in multiple myeloma. Oncotarget 2020, 11, 3984-3997. [CrossRef]

63. Zhao, X.; Wang, X.; Fang, L.; Lan, C.; Zheng, X.; Wang, Y.; Zhang, Y.; Han, X.; Liu, S.; Cheng, K.; et al. A combinatorial strategy using YAP and pan-RAF inhibitors for treating KRAS-mutant pancreatic cancer. Cancer Lett. 2017, 402, 61-70. [CrossRef]

64. Wei, W.J.; Sun, Z.K.; Shen, C.T.; Song, H.J.; Zhang, X.Y.; Qiu, Z.L.; Luo, Q.Y. Obatoclax and LY3009120 efficiently overcome Vemurafenib resistance in Differentiated Thyroid Cancer. Theranostics 2017, 7, 987-1001. [CrossRef] [PubMed]

65. Girotti, M.R.; Lopes, F.; Preece, N.; Niculescu-Duvaz, D.; Zambon, A.; Davies, L.; Whittaker, S.; Saturno, G.; Viros, A.; Pedersen, M.; et al. Paradox-breaking RAF inhibitors that also target SRC are effective in drug-resistant BRAF mutant melanoma. Cancer Cell 2015, 27, 85-96. [CrossRef]

66. Chen, S.H.; Gong, X.; Zhang, Y.; Van Horn, R.D.; Yin, T.; Huber, L.; Burke, T.F.; Manro, J.; Iversen, P.W.; Wu, W.; et al. RAF inhibitor LY3009120 sensitizes RAS or BRAF mutant cancer to CDK4/ 6 inhibition by abemaciclib via superior inhibition of phospho-RB and suppression of cyclin D1. Oncogene 2018, 37, 821-832. [CrossRef] [PubMed]

67. Sullivan, R.J.; Hollebecque, A.; Flaherty, K.T.; Shapiro, G.I.; Ahnert, J.R.; Millward, M.J.; Zhang, W.; Gao, L.; Sykes, A.; Willard, M.D.; et al. A phase I study of LY3009120, a pan-RAF inhibitor, in patients with advanced or metastatic cancer. Mol. Cancer Ther. 2020, 19, 460-467. [CrossRef] 
68. Saturno, G.; Lopes, F.; Niculescu-Duvaz, I.; Niculescu-Duvaz, D.; Zambon, A.; Davies, L.; Johnson, L.; Preece, N.; Lee, R.; Viros, A.; et al. The paradox-breaking panRAF plus SRC family kinase inhibitor, CCT3833, is effective in mutant KRAS-driven cancers. Ann. Oncol. 2021, 32, 269-278. [CrossRef] [PubMed]

69. Desai, J.; Gan, H.; Barrow, C.; Jameson, M.; Atkinson, V.; Haydon, A.; Millward, M.; Begbie, S.; Brown, M.; Markman, B.; et al. Phase I, open-label, dose-escalation/ dose-expansion study of lifirafenib (BGB-283), an RAF family kinase inhibitor, in patients with solid tumors. J. Clin. Oncol. 2020, 38, 2140-2150. [CrossRef]

70. Ramurthy, S.; Taft, B.R.; Aversa, R.J.; Barsanti, P.A.; Burger, M.T.; Lou, Y.; Nishiguchi, G.A.; Rico, A.; Setti, L.; Smith, A.; et al. Design and Discovery of N-(3-(2-(2-Hydroxyethoxy)-6-morpholinopyridin-4-yl)-4-methylphenyl)-2-(trifluoromethyl)isonicotinamide, a Selective, Ef-ficacious, and Well-Tolerated RAF Inhibitor Targeting RAS Mutant Cancers: The Path to the Clinic. J. Med. Chem. 2020, 63, 2013-2027. [CrossRef]

71. Park, S.; Kim, T.M.; Cho, S.Y.; Kim, S.; Oh, Y.; Kim, M.; Keam, B.; Kim, D.W.; Heo, D.S. Combined blockade of polo-like kinase and pan-RAF is effective against NRAS-mutant non-small cell lung cancer cells. Cancer Lett. 2020, 495, 135-144. [CrossRef]

72. Kim, T.W.; Lee, J.; Shin, S.J.; Kim, J.-S.; Kim, Y.J.; Han, H.S.; Lee, S.J.; Lim, H.-S.; Hong, Y.; Noh, Y.S.; et al. Belvarafenib, a novel pan-RAF inhibitor, in solid tumor patients harboring BRAF, KRAS, or NRAS mutations: Phase I study. J. Clin. Oncol. 2019, 37, 3000. [CrossRef]

73. Rukhlenko, O.S.; Khorsand, F.; Krstic, A.; Rozanc, J.; Alexopoulos, L.G.; Rauch, N.; Erickson, K.E.; Hlavacek, W.S.; Posner, R.G.; Gómez-Coca, S.; et al. Dissecting RAF Inhibitor Resistance by Structure-based Modeling Reveals Ways to Overcome Oncogenic RAS Signaling. Cell Syst. 2018, 7, 161-179.e14. [CrossRef]

74. Yuan, X.; Tang, Z.; Du, R.; Yao, Z.; Cheung, S.H.; Zhang, X.; Wei, J.; Zhao, Y.; Du, Y.; Liu, Y.; et al. RAF dimer inhibition enhances the antitumor activity of MEK inhibitors in K-RAS mutant tumors. Mol. Oncol. 2020, 14, 1833-1849. [CrossRef] [PubMed]

75. Desai, J.; Gan, H.; Barrow, C.; Jameson, M.B.; Solomon, B.; Atkinson, V.; Haydon, A.; Millward, M.; Begbie, S.; Brown, M.; et al. Abstract CT002: A Phase IB study of RAF dimer inhibitor BGB-283 in patients with B-RAF or K-RAS/N-RAS mutated solid tumors. In Proceedings of the AACR Annual Meeting 2017, Washington, DC, USA, 1-5 April 2017; Volume 77, p. CT002.

76. Zhang, C.; Spevak, W.; Zhang, Y.; Burton, E.A.; Ma, Y.; Habets, G.; Zhang, J.; Lin, J.; Ewing, T.; Matusow, B.; et al. RAF inhibitors that evade paradoxical MAPK pathway activation. Nature 2015, 526, 583-586. [CrossRef]

77. Yao, Z.; Gao, Y.; Su, W.; Yaeger, R.; Tao, J.; Na, N.; Zhang, Y.; Zhang, C.; Rymar, A.; Tao, A.; et al. RAF inhibitor PLX8394 selectively disrupts BRAF dimers and RAS-independent BRAF-mutant-driven signaling. Nat. Med. 2019, 25, 284-291. [CrossRef] [PubMed]

78. Freeman, A.K.; Ritt, D.A.; Morrison, D.K. Effects of Raf Dimerization and Its Inhibition on Normal and Disease-Associated Raf Signaling. Mol. Cell 2013, 49, 751-758. [CrossRef]

79. Rajakulendran, T.; Sahmi, M.; Lefrançois, M.; Sicheri, F.; Therrien, M. A dimerization-dependent mechanism drives RAF catalytic activation. Nature 2009, 461, 542-545. [CrossRef]

80. Beneker, C.M.; Rovoli, M.; Kontopidis, G.; Röring, M.; Galda, S.; Braun, S.; Brummer, T.; McInnes, C. Design and Synthesis of Type-IV Inhibitors of BRAF Kinase That Block Dimerization and Overcome Paradoxical MEK/ERK Activation. J. Med. Chem. 2019, 62, 3886-3897. [CrossRef]

81. Gunderwala, A.Y.; Nimbvikar, A.A.; Cope, N.J.; Li, Z.; Wang, Z. Development of Allosteric BRAF Peptide Inhibitors Tar-geting the Dimer Interface of BRAF. ACS Chem. Biol. 2019, 14, 1471-1480. [CrossRef] [PubMed]

82. Cope, N.J.; Novak, B.; Liu, Z.; Cavallo, M.; Gunderwala, A.Y.; Connolly, M.; Wang, Z. Analyses of the oncogenic BRAFD594G variant reveal a kinase-independent function of BRAF in activating MAPK signaling. J. Biol. Chem. 2020, 295, 2407-2420. [CrossRef]

83. Blasco, R.B.; Francoz, S.; Santamaría, D.; Cañamero, M.; Dubus, P.; Charron, J.; Baccarini, M.; Barbacid, M. C-Raf, but Not B-Raf, Is Essential for Development of K-Ras Oncogene-Driven Non-Small Cell Lung Carcinoma. Cancer Cell 2011, 19, 652-663. [CrossRef]

84. Blasco, M.T.; Navas, C.; Martín-Serrano, G.; Graña-Castro, O.; Lechuga, C.G.; Martín-Díaz, L.; Djurec, M.; Li, J.; Mo-rales-Cacho, L.; Esteban-Burgos, L.; et al. Complete Regression of Advanced Pancreatic Ductal Adenocarcinomas upon Combined Inhibition of EGFR and C-RAF. Cancer Cell 2019, 35, 573-587.e6. [CrossRef]

85. Sanclemente, M.; Francoz, S.; Esteban-Burgos, L.; Bousquet-Mur, E.; Djurec, M.; Lopez-Casas, P.P.; Hidalgo, M.; Guerra, C.; Drosten, M.; Musteanu, M.; et al. c-RAF Ablation Induces Regression of Advanced Kras/Trp53 Mutant Lung Adenocarci-nomas by a Mechanism Independent of MAPK Signaling. Cancer Cell 2018, 33, 217-228.e4. [CrossRef]

86. Morgan, C.W.; Dale, I.L.; Thomas, A.P.; Hunt, J.; Chin, J.W. Selective CRAF Inhibition Elicits Transactivation. J. Am. Chem. Soc. 2021, 143, 4600-4606. [CrossRef] [PubMed]

87. McCormick, F. c-Raf in KRas Mutant Cancers: A Moving Target. Cancer Cell 2018, 33, 158-159. [CrossRef]

88. Nolan, A.A.; Aboud, N.K.; Kolch, W.; Matallanas, D. Hidden Targets in RAF Signalling Pathways to Block Oncogenic RAS Signalling. Genes 2021, 12, 553. [CrossRef] [PubMed]

89. Ohren, J.F.; Chen, H.; Pavlovsky, A.; Whitehead, C.; Zhang, E.; Kuffa, P.; Yan, C.; McConnell, P.; Spessard, C.; Banotai, C.; et al. Structures of human MAP kinase kinase 1 (MEK1) and MEK2 describe novel noncompetitive kinase inhibition. Nat. Struct. Mol. Biol. 2004, 11, 1192-1197. [CrossRef]

90. Zhao, Y.; Adjei, A.A. The clinical development of MEK inhibitors. Nat. Rev. Clin. Oncol. 2014, 11, 385-400. [CrossRef] [PubMed]

91. Wee, S.; Jagani, Z.; Kay, X.X.; Loo, A.; Dorsch, M.; Yao, Y.M.; Sellers, W.R.; Lengauer, C.; Stegmeier, F. PI3K pathway activation mediates resistance to MEK inhibitors in KRAS mutant cancers. Cancer Res. 2009, 69, 4286-4293. [CrossRef] 
92. Sun, C.; Hobor, S.; Bertotti, A.; Zecchin, D.; Huang, S.; Galimi, F.; Cottino, F.; Prahallad, A.; Grernrum, W.; Tzani, A.; et al. Intrinsic resistance to MEK inhibition in kras mutant lung and colon cancer through transcriptional induction of ERBB3. Cell Rep. 2014, 7, 86-93. [CrossRef]

93. Johnson, G.L.; Stuhlmiller, T.J.; Angus, S.P.; Zawistowski, J.S.; Graves, L.M. Molecular pathways: Adaptive Kinome reprogramming in response to targeted inhibition of the BRAF-MEK-ERK pathway in cancer. Clin. Cancer Res. 2014, 20, 2516-2522. [CrossRef] [PubMed]

94. Komatsu, N.; Fujita, Y.; Matsuda, M.; Aoki, K. mTORC1 upregulation via ERK-dependent gene expression change confers intrinsic resistance to MEK inhibitors in oncogenic KRas-mutant cancer cells. Oncogene 2015, 34, 5607-5616. [CrossRef]

95. Blumenschein, G.R.; Smit, E.F.; Planchard, D.; Kim, D.W.; Cadranel, J.; De Pas, T.; Dunphy, F.; Udud, K.; Ahn, M.J.; Hanna, N.H.; et al. A randomized phase II study of the MEK1/MEK2 inhibitor trametinib (GSK1120212) compared with docetaxel in KRAS-mutant advanced non-small-cell lung cancer (NSCLC). Ann. Oncol. 2015, 26, 894-901. [CrossRef] [PubMed]

96. Carter, C.A.; Rajan, A.; Keen, C.; Szabo, E.; Khozin, S.; Thomas, A.; Brzezniak, C.; Guha, U.; Doyle, L.A.; Steinberg, S.M.; et al. Selumetinib with and without erlotinib in KRAS mutant and KRAS wild-type advanced nonsmall-cell lung cancer. Ann. Oncol. 2016, 27, 693-699. [CrossRef] [PubMed]

97. Jänne, P.A.; Van Den Heuvel, M.M.; Barlesi, F.; Cobo, M.; Mazieres, J.; Crinò, L.; Orlov, S.; Blackhall, F.; Wolf, J.; Garrido, P.; et al. Selumetinib plus docetaxel compared with docetaxel alone and progression-free survival in patients with KRAS-mutant advanced non-small cell lung cancer: The SELECT-1 randomized clinical trial. JAMA J. Am. Med. Assoc. 2017, 317, 1844-1853. [CrossRef]

98. Dummer, R.; Schadendorf, D.; Ascierto, P.A.; Arance, A.; Dutriaux, C.; Di Giacomo, A.M.; Rutkowski, P.; Del Vecchio, M.; Gutzmer, R.; Mandala, M.; et al. Binimetinib versus dacarbazine in patients with advanced NRAS-mutant melanoma (NEMO): A multicentre, open-label, randomised, phase 3 trial. Lancet Oncol. 2017, 18, 435-445. [CrossRef]

99. Li, S.; Liu, S.; Deng, J.; Akbay, E.A.; Hai, J.; Ambrogio, C.; Zhang, L.; Zhou, F.; Jenkins, R.W.; Adeegbe, D.O.; et al. Assessing therapeutic efficacy of MEK inhibition in a KrasG12C-driven mouse model of lung cancer. Clin. Cancer Res. 2018, 24, 4854-4864. [CrossRef] [PubMed]

100. Holt, S.V.; Logié, A.; Odedra, R.; Heier, A.; Heaton, S.P.; Alferez, D.; Davies, B.R.; Wilkinson, R.W.; Smith, P.D. The MEK1/2 inhibitor, selumetinib (AZD6244; ARRY-142886), enhances anti-tumour efficacy when combined with conventional chemotherapeutic agents in human tumour xenograft models. Br. J. Cancer 2012, 106, 858-866. [CrossRef]

101. Queirolo, P.; Spagnolo, F. Binimetinib for the treatment of NRAS-mutant melanoma. Expert Rev. Anticancer Ther. 2017, 17, 985-990. [CrossRef] [PubMed]

102. Yarchoan, M.; Mohan, A.A.; Dennison, L.; Vithayathil, T.; Ruggieri, A.; Lesinski, G.B.; Armstrong, T.D.; Azad, N.S.; Jaffee, E.M. MEK inhibition suppresses B regulatory cells and augments anti-tumor immunity. PLoS ONE 2019, 14, e0224600. [CrossRef]

103. Chapman, P.B.; Solit, D.B.; Rosen, N. Combination of RAF and MEK Inhibition for the Treatment of BRAF-Mutated Mel-anoma: Feedback Is Not Encouraged. Cancer Cell 2014, 26, 603-604. [CrossRef] [PubMed]

104. Lamba, S.; Russo, M.; Sun, C.; Lazzari, L.; Cancelliere, C.; Grernrum, W.; Lieftink, C.; Bernards, R.; DiNicolantonio, F.; Bardelli, A. RAF Suppression Synergizes with MEK Inhibition in KRAS Mutant Cancer Cells. Cell Rep. 2014, 8, 1475-1483. [CrossRef]

105. Lee, J.W.; Zhang, Y.; Eoh, K.J.; Sharma, R.; Sanmamed, M.F.; Wu, J.; Choi, J.; Park, H.S.; Iwasaki, A.; Kaftan, E.; et al. The Combination of MEK Inhibitor with Immunomodulatory Antibodies Targeting Programmed Death 1 and Programmed Death Ligand 1 Results in Prolonged Survival in Kras/p53-Driven Lung Cancer. J. Thorac. Oncol. 2019, 14, 1046-1060. [CrossRef]

106. Wang, Y.; Hou, N.; Cheng, X.; Zhang, J.; Tan, X.; Zhang, C.; Tang, Y.; Teng, Y.; Yang, X. Ezh2 acts as a tumor suppressor in kras-driven lung adenocarcinoma. Int. J. Biol. Sci. 2017, 13, 652-659. [CrossRef]

107. Berg, J.L.; Perfler, B.; Hatzl, S.; Uhl, B.; Reinisch, A.; Pregartner, G.; Berghold, A.; Penz, T.; Schuster, M.; Geissler, K.; et al. EZH2 inactivation in RAS-driven myeloid neoplasms hyperactivates RAS-signaling and increases MEK inhibitor sensitivity. Leukemia 2021, 35, 1521-1526. [CrossRef] [PubMed]

108. Hofmann, M.H.; Gmachl, M.; Ramharter, J.; Savarese, F.; Gerlach, D.; Marszalek, J.R.; Sanderson, M.P.; Kessler, D.; Trapani, F.; Arnhof, H.; et al. Bi-3406, a potent and selective sos1-kras interaction inhibitor, is effective in kras-driven cancers through combined mek inhibition. Cancer Discov. 2021, 11, 142-157. [CrossRef]

109. Ruess, D.A.; Heynen, G.J.; Ciecielski, K.J.; Ai, J.; Berninger, A.; Kabacaoglu, D.; Görgülü, K.; Dantes, Z.; Wörmann, S.M.; Diakopoulos, K.N.; et al. Mutant KRAS-driven cancers depend on PTPN11/SHP2 phosphatase. Nat. Med. 2018, 24, 954-960. [CrossRef] [PubMed]

110. Wong, G.S.; Zhou, J.; Liu, J.B.; Wu, Z.; Xu, X.; Li, T.; Xu, D.; Schumacher, S.E.; Puschhof, J.; McFarland, J.; et al. Targeting wild-type KRAS-amplified gastroesophageal cancer through combined MEK and SHP2 inhibition letter. Nat. Med. 2018, 24, 968-977. [CrossRef]

111. Wada, M.; Horinaka, M.; Yamazaki, T.; Katoh, N.; Sakai, T. The dual RAF/MEK inhibitor CH5126766/RO5126766 may be a potential therapy for RAS-mutated tumor cells. PLoS ONE 2014, 9, e113217. [CrossRef]

112. Nakagawa, N.; Kikuchi, K.; Yagyu, S.; Miyachi, M.; Iehara, T.; Tajiri, T.; Sakai, T.; Hosoi, H. Mutations in the RAS pathway as potential precision medicine targets in treatment of rhabdomyosarcoma. Biochem. Biophys. Res. Commun. 2019, 512, 524-530. [CrossRef] [PubMed]

113. Umemura, S.; Sowa, Y.; Iizumi, Y.; Kitawaki, J.; Sakai, T. Synergistic effect of the inhibitors of RAF/MEK and AXL on KRASmutated ovarian cancer cells with high AXL expression. Cancer Sci. 2020, 111, 2052-2061. [CrossRef] [PubMed] 
114. Ishii, N.; Harada, N.; Joseph, E.W.; Ohara, K.; Miura, T.; Sakamoto, H.; Matsuda, Y.; Tomii, Y.; Tachibana-Kondo, Y.; Iikura, H.; et al. Enhanced inhibition of ERK signaling by a novel allosteric MEK inhibitor, CH5126766, that suppresses feedback reactivation of raf activity. Cancer Res. 2013, 73, 4050-4060. [CrossRef]

115. Chenard-Poirier, M.; Kaiser, M.; Boyd, K.; Sriskandarajah, P.; Constantinidou, A.; Harris, S.J.; Serrano Fandos, S.; Ryan, A.; Witt, K.; Dawes, J.C.; et al. Results from the biomarker-driven basket trial of RO5126766 (CH5127566), a potent RAF/MEK inhibitor, in RAS- or RAF-mutated malignancies including multiple myeloma. J. Clin. Oncol. 2017, 35, 2506. [CrossRef]

116. Guo, C.; Chénard-Poirier, M.; Roda, D.; de Miguel, M.; Harris, S.J.; Candilejo, I.M.; Sriskandarajah, P.; Xu, W.; Scaranti, M.; Constantinidou, A.; et al. Intermittent schedules of the oral RAF-MEK inhibitor CH5126766/VS-6766 in patients with RAS/RAFmutant solid tumours and multiple myeloma: A single-centre, open-label, phase 1 dose-escalation and basket dose-expansion study. Lancet Oncol. 2020, 21, 1478-1488. [CrossRef]

117. Martinez-Garcia, M.; Banerji, U.; Albanell, J.; Bahleda, R.; Dolly, S.; Kraeber-Bodéré, F.; Rojo, F.; Routier, E.; Guarin, E.; Xu, Z.X.; et al. First-in-human, phase I dose-escalation study of the safety, pharmacokinetics, and pharmacodynamics of RO5126766, a first-in-class dual MEK/RAF inhibitor in patients with solid tumors. Clin. Cancer Res. 2012, 18, 4806-4819. [CrossRef] [PubMed]

118. Tao, Z.; Le Blanc, J.M.; Wang, C.; Zhan, T.; Zhuang, H.; Wang, P.; Yuan, Z.; Lu, B. Coadministration of trametinib and palbociclib radiosensitizes KRAS-mutant non-small cell lung cancers in vitro and in vivo. Clin. Cancer Res. 2016, 22, 122-133. [CrossRef] [PubMed]

119. Malumbres, M.; Barbacid, M. To cycle or not to cycle: A critical decision in cancer. Nat. Rev. Cancer 2001, 1, 222-231. [CrossRef]

120. Ascierto, P.A.; Schadendorf, D.; Berking, C.; Agarwala, S.S.; van Herpen, C.M.L.; Queirolo, P.; Blank, C.U.; Hauschild, A.; Beck, J.T.; St-Pierre, A.; et al. MEK162 for patients with advanced melanoma harbouring NRAS or Val600 BRAF mutations: A non-randomised, open-label phase 2 study. Lancet Oncol. 2013, 14, 249-256. [CrossRef]

121. Jänne, P.A.; Mann, H.; Ghiorghiu, D. Study Design and Rationale for a Randomized, Placebo-Controlled, Double-Blind Study to Assess the Efficacy and Safety of Selumetinib in Combination with Docetaxel as Second-Line Treatment in Patients with KRAS-Mutant Advanced Non-Small Cell Lung Cancer (SELECT-1). Clin. Lung Cancer 2016, 17, e1-e4. [CrossRef]

122. Pant, S.; Bendell, J.C.; Sullivan, R.J.; Shapiro, G.; Millward, M.; Mi, G.; Yuen, E.; Willard, M.D.; Wang, D.; Joseph, S.; et al. A phase I dose escalation (DE) study of ERK inhibitor, LY3214996, in advanced (adv) cancer (CA) patients (pts). J. Clin. Oncol. 2019, 37, 3001. [CrossRef]

123. Wu, W.; Bhagwat, S.V.; King, C.; Pratt, S.; Gong, X.; Stewart, J.; Jones, B.; Flack, R.; Beckman, R.; Falcon, B.; et al. Abstract 317: Combination of a novel ERK1/2 inhibitor (LY3214996) with CDK4 and CDK6 inhibitor (abemaciclib) enhances anti-tumor efficacy in KRAS mutant non-small cell lung cancer (NSCLC). In Proceedings of the AACR Annual Meeting 2017, Washington, DC, USA, 1-5 April 2017; Volume 77, p. 317.

124. Portelinha, A.; Thompson, S.; Smith, R.A.; Ferreira, M.D.S.; Asgari, Z.; Knezevic, A.; Seshan, V.; de Stanchina, E.; Gupta, S.; Denis, L.; et al. Discovery of Asn007, a Novel Inhibitor of Erk1/2, with a Preferential Activity in RAS- and RAF-Mutant Tumors. SSRN Electron. J. 2020. [CrossRef]

125. Köhler, J.; Zhao, Y.; Li, J.; Gokhale, P.C.; Tiv, H.L.; Knott, A.R.; Wilkens, M.K.; Soroko, K.M.; Lin, M.; Ambrogio, C.; et al. ERK Inhibitor LY3214996-Based Treatment Strategies for RAS-Driven Lung Cancer. Mol. Cancer Ther. 2021, 20, 641-654. [CrossRef]

126. Robarge, K.; Schwarz, J.; Blake, J.; Burkard, M.; Chan, J.; Chen, H.; Chou, K.-J.; Diaz, D.; Gaudino, J.; Gould, S.; et al. Abstract DDT02-03: Discovery of GDC-0994, a potent and selective ERK1/2 inhibitor in early clinical development. Am. Assoc. Cancer Res. 2014, 74, DDT02-DDT03.

127. Moschos, S.J.; Sullivan, R.J.; Hwu, W.J.; Ramanathan, R.K.; Adjei, A.A.; Fong, P.C.; Shapira-Frommer, R.; Tawbi, H.A.; Rubino, J.; Rush, T.S.; et al. Development of MK-8353, an orally administered ERK1/2 inhibitor, in patients with advanced solid tumors. JCI Insight 2018, 3, e92352. [CrossRef]

128. Blake, J.F.; Burkard, M.; Chan, J.; Chen, H.; Chou, K.J.; Diaz, D.; Dudley, D.A.; Gaudino, J.J.; Gould, S.E.; Grina, J.; et al. Discovery of (S)-1-(1-(4-Chloro-3-fluorophenyl)-2-hydroxyethyl)-4-(2-((1-methyl-1H-pyrazol-5-yl)amino)pyrimidin-4-yl)pyridin-2(1H)-one (GDC-0994), an Extracellular Signal-Regulated Kinase 1/2 (ERK1/2) Inhibitor in Early Clinical Development. J. Med. Chem. 2016, 59, 5650-5660. [CrossRef] [PubMed]

129. Merchant, M.; Moffat, J.; Schaefer, G.; Chan, J.; Wang, X.; Orr, C.; Cheng, J.; Hunsaker, T.; Shao, L.; Wang, S.J.; et al. Combined MEK and ERK inhibition overcomes therapy-mediated pathway reactivation in RAS mutant tumors. PLoS ONE 2017, 12, e0185862. [CrossRef]

130. Fourneaux, B.; Chaire, V.; Karanian, M.; Laroche, A.; Italiano, A. Abstract 4636: Dual targeting of PI3K/mTOR leads to MEK/ERK over-activation in leiomyosarcoma through suppression of mTORC2 inhibition. In Proceedings of the AACR Annual Meeting 2016, New Orleans, LA, USA, 16-20 April 2016; Volume 76, p. 4636.

131. Varga, A.; Soria, J.C.; Hollebecque, A.; LoRusso, P.; Vaishampayan, U.; Okrah, K.; Huang, S.M.A.; Murray, E.; Sana-bria-Bohorquez, S.; Tagen, M.; et al. A first-in-human phase I study to evaluate the ERK1/2 inhibitor GDC-0994 in patients with advanced solid tumors. Eur. J. Cancer 2016, 69, S11. [CrossRef]

132. Weekes, C.; Lockhart, A.; LoRusso, P.; Murray, E.; Park, E.; Tagen, M.; Singh, J.; Sarkar, I.; Mueller, L.; Dokainish, H.; et al. A Phase Ib Study to Evaluate the MEK Inhibitor Cobimetinib in Combination with the ERK1 / 2 Inhibitor GDC -0994 in Pa-tients with Advanced Solid Tumors. Oncologist 2020, 25, 833. [CrossRef] [PubMed] 
133. Bhagwat, S.V.; McMillen, W.T.; Cai, S.; Zhao, B.; Whitesell, M.; Kindler, L.; Flack, R.S.; Wu, W.; Huss, K.; Anderson, B.; et al. Abstract 4973: Discovery of LY3214996, a selective and novel ERK1/2 inhibitor with potent antitumor activities in cancer models with MAPK pathway alterations. In Proceedings of the AACR Annual Meeting 2017, Washington, DC, USA, 1-5 April 2017; Volume 77, p. 4973.

134. Bhagwat, S.V.; McMillen, W.T.; Cai, S.; Zhao, B.; Whitesell, M.; Shen, W.; Kindler, L.; Flack, R.S.; Wu, W.; Anderson, B.; et al. ERK inhibitor LY3214996 targets ERK pathway-driven cancers: A therapeutic approach toward precision medicine. Mol. Cancer Ther. 2020, 19, 325-336. [CrossRef]

135. Reddy, S.P.; Thompson, S.K.; Usansky, H.; Smith, R.A.; Denis, L.; Gupta, S. Abstract B05: ASN007, an oral ERK1/2 inhibitor, shows strong antitumor activity across a panel of KRAS subtype mutant cancer models. Mol. Cancer Res. 2020, 18, B05. [CrossRef]

136. Germann, U.A.; Furey, B.F.; Markland, W.; Hoover, R.R.; Aronov, A.M.; Roix, J.J.; Hale, M.; Boucher, D.M.; Sorrell, D.A.; MartinezBotella, G.; et al. Targeting the MAPK Signaling Pathway in Cancer: Promising Preclinical Activity with the Novel Selective ERK1/2 Inhibitor BVD-523 (Ulixertinib). Mol. Cancer Ther. 2017, 16, 2351-2363. [CrossRef] [PubMed]

137. Sullivan, R.J.; Infante, J.R.; Janku, F.; Lee Wong, D.J.; Sosman, J.A.; Keedy, V.; Patel, M.R.; Shapiro, G.I.; Mier, J.W.; Tolcher, A.W.; et al. First-in-class ERK1/2 inhibitor ulixertinib (BVD-523) in patients with MAPK mutant advanced solid tumors: Results of a phase I dose-escalation and expansion study. Cancer Discov. 2018, 8, 184-195. [CrossRef] [PubMed]

138. Jiang, H.; Xu, M.; Li, L.; Grierson, P.; Dodhiawala, P.; Highkin, M.; Zhang, D.; Li, Q.; Wang-Gillam, A.; Lim, K.-H. Concurrent HER or PI3K Inhibition Potentiates the Antitumor Effect of the ERK Inhibitor Ulixertinib in Preclinical Pancreatic Cancer Models. Mol. Cancer Ther. 2018, 17, 2144-2155. [CrossRef] [PubMed]

139. Flemington, V.; Davies, E.J.; Robinson, D.; Sandin, L.C.; Delpuech, O.; Zhang, P.; Hanson, L.; Farrington, P.; Bell, S.; Falenta, K.; et al. AZD0364 Is a potent and selective erk1/2 inhibitor that enhances antitumor activity in KRAS-mutant tumor models when combined with the MEK inhibitor, selumetinib. Mol. Cancer Ther. 2021, 20, 238-249. [CrossRef] [PubMed]

140. Catalano, A.; Adlesic, M.; Kaltenbacher, T.; Klar, R.F.U.; Albers, J.; Seidel, P.; Brandt, L.P.; Hejhal, T.; Busenhart, P.; Röhner, N.; et al. Sensitivity and Resistance of Oncogenic RAS-Driven Tumors to Dual MEK and ERK Inhibition. Cancers 2021, 13, 1852. [CrossRef]

141. Ozkan-Dagliyan, I.; Diehl, J.N.; George, S.D.; Schaefer, A.; Papke, B.; Klotz-Noack, K.; Waters, A.M.; Goodwin, C.M.; Gautam, P.; Pierobon, M.; et al. Low-Dose Vertical Inhibition of the RAF-MEK-ERK Cascade Causes Apoptotic Death of KRAS Mutant Cancers. Cell Rep. 2020, 31, 107764. [CrossRef]

142. Plotnikov, A.; Flores, K.; Maik-Rachline, G.; Zehorai, E.; Kapri-Pardes, E.; Berti, D.A.; Hanoch, T.; Besser, M.J.; Seger, R. The nuclear translocation of ERK1/2 as an anticancer target. Nat. Commun. 2015, 6, 6685. [CrossRef]

143. Maik-Rachline, G.; Hacohen-Lev-Ran, A.; Seger, R. Nuclear erk: Mechanism of translocation, substrates, and role in cancer. Int. J. Mol. Sci. 2019, 20, 1194. [CrossRef]

144. Arafeh, R.; Flores, K.; Keren-Paz, A.; Maik-Rachline, G.; Gutkind, N.; Rosenberg, S.; Seger, R.; Samuels, Y. Combined inhi-bition of MEK and nuclear ERK translocation has synergistic antitumor activity in melanoma cells. Sci. Rep. 2017, 7, 16345. [CrossRef]

145. Nishimoto, S.; Nishida, E. MAPK signalling: ERK5 versus ERK1/2. EMBO Rep. 2006, 7, 782-786. [CrossRef]

146. Benito-Jardon, L.; Díaz-Martínez, M.; Arellano-Sanchez, N.; Vaquero-Morales, P.; Esparís-Ogando, A.; Teixido, J. Resistance to MAPK inhibitors in melanoma involves activation of the IGF1R-MEK5-Erk5 pathway. Cancer Res. 2019, 79, 2244-2256. [CrossRef]

147. De Jong, P.R.; Taniguchi, K.; Harris, A.R.; Bertin, S.; Takahashi, N.; Duong, J.; Campos, A.D.; Powis, G.; Corr, M.; Karin, M.; et al. ERK5 signalling rescues intestinal epithelial turnover and tumour cell proliferation upon ERK1/2 abrogation. Nat. Commun. 2016, 7, 1-15. [CrossRef]

148. Adam, C.; Fusi, L.; Weiss, N.; Goller, S.G.; Meder, K.; Frings, V.G.; Kneitz, H.; Goebeler, M.; Houben, R.; Schrama, D.; et al. Efficient Suppression of NRAS-Driven Melanoma by Co-Inhibition of ERK1/2 and ERK5 MAPK Pathways. J. Investig. Dermatol. 2020, 140, 2455-2465.e10. [CrossRef] [PubMed]

149. Tenbaum, S.P.; Ordóñez-Morán, P.; Puig, I.; Chicote, I.; Arqués, O.; Landolfi, S.; Fernández, Y.; Herance, J.R.; Gispert, J.D.; Mendizabal, L.; et al. $\beta$-Catenin confers resistance to PI3K and AKT inhibitors and subverts FOXO3a to promote metastasis in colon cancer. Nat. Med. 2012, 18, 892-901. [CrossRef]

150. Serra, V.; Eichhorn, P.J.A.; García-García, C.; Ibrahim, Y.H.; Prudkin, L.; Sánchez, G.; Rodríguez, O.; Antón, P.; Parra, J.L.; Marlow, S.; et al. RSK3/4 mediate resistance to PI3K pathway inhibitors in breast cancer. J. Clin. Investig. 2013, 123, 2551-2563. [CrossRef]

151. Ray-David, H.; Romeo, Y.; Lavoie, G.; Déléris, P.; Tcherkezian, J.; Galan, J.A.; Roux, P.P. RSK promotes G2 DNA damage checkpoint silencing and participates in melanoma chemoresistance. Oncogene 2013, 32, 4480-4489. [CrossRef]

152. Markham, A. Alpelisib: First Global Approval. Drugs 2019, 79, 1249-1253. [CrossRef] [PubMed]

153. Dolgikh, N.; Hugle, M.; Vogler, M.; Fulda, S. Nras-mutated rhabdomyosarcoma cells are vulnerable to mitochondrial apoptosis induced by coinhibition of mek and pi3ka. Cancer Res. 2018, 78, 2000-2013. [CrossRef]

154. Burrows, F.; Shivani, M.; Wang, Z.; Chan, S.; Gilardi, M.; Gutkind, S. Antitumor activity of tipifarnib and PI3K pathway inhibitors in HRAS-associated head and neck squamous cell carcinoma. Eur. J. Cancer 2020, 138, S43-S44. [CrossRef]

155. Kim, M.J.; Lee, S.J.; Ryu, J.H.; Kim, S.H.; Kwon, I.C.; Roberts, T.M. Combination of KRAS gene silencing and PI3K inhibition for ovarian cancer treatment. J. Control Release 2020, 318, 98-108. [CrossRef]

156. Chakraborty, C.; Sharma, A.R.; Sharma, G.; Doss, C.G.P.; Lee, S.S. Therapeutic miRNA and siRNA: Moving from Bench to Clinic as Next Generation Medicine. Mol. Ther. Nucleic Acids 2017, 8, 132-143. [CrossRef]

157. Hollander, M.C.; Maier, C.R.; Hobbs, E.A.; Ashmore, A.R.; Linnoila, R.I.; Dennis, P.A. Akt1 deletion prevents lung tumor-igenesis by mutant K-ras. Oncogene 2011, 30, 1812-1821. [CrossRef] [PubMed] 
158. Rao, G.; Pierobon, M.; Kim, I.K.; Hsu, W.H.; Deng, J.; Moon, Y.W.; Petricoin, E.F.; Zhang, Y.W.; Wang, Y.; Giaccone, G. Inhibition of AKT1 signaling promotes invasion and metastasis of non-small cell lung cancer cells with K-RAS or EGFR mutations. Sci. Rep. 2017, 7, 1-12. [CrossRef] [PubMed]

159. Li, W.; Hou, J.Z.; Niu, J.; Xi, Z.Q.; Ma, C.; Sun, H.; Wang, C.J.; Fang, D.; Li, Q.; Xie, S.Q. Akt1 inhibition promotes breast cancer metastasis through EGFR-mediated $\beta$-catenin nuclear accumulation. Cell Commun. Signal. 2018, 16, 1-13. [CrossRef]

160. Song, Q.; Sun, X.; Guo, H.; Yu, Q. Concomitant inhibition of receptor tyrosine kinases and downstream AKT synergistically inhibited growth of KRAS/BRAF mutant colorectal cancer cells. Oncotarget 2017, 8, 5003-5015. [CrossRef] [PubMed]

161. Feng, S.; Shao, L.; Castro, P.; Coleman, I.; Nelson, P.S.; Smith, P.D.; Davies, B.R.; Ittmann, M. Combination treatment of prostate cancer with FGF receptor and AKT kinase inhibitors. Oncotarget 2017, 8, 6179-6192. [CrossRef]

162. O’Reilly, K.E.; Rojo, F.; She, Q.B.; Solit, D.; Mills, G.B.; Smith, D.; Lane, H.; Hofmann, F.; Hicklin, D.J.; Ludwig, D.L.; et al. mTOR inhibition induces upstream receptor tyrosine kinase signaling and activates Akt. Cancer Res. 2006, 66, 1500-1508. [CrossRef]

163. Soares, H.P.; Ming, M.; Mellon, M.; Young, S.H.; Han, L.; Sinnet-Smith, J.; Rozengurt, E. Dual PI3K/mTOR inhibitors induce rapid overactivation of the MEK/ERK pathway in human pancreatic cancer cells through suppression of mTORC2. Mol. Cancer Ther. 2015, 14, 1014-1023. [CrossRef]

164. West, A.C.; Johnstone, R.W. New and emerging HDAC inhibitors for cancer treatment. J. Clin. Investig. 2014, 124, 30-39. [CrossRef]

165. Malone, C.F.; Emerson, C.; Ingraham, R.; Barbosa, W.; Guerra, S.; Yoon, H.; Liu, L.L.; Michor, F.; Haigis, M.; Macleod, K.F.; et al mTOR and HDAC inhibitors converge on the TXNIP/thioredoxin pathway to cause catastrophic oxidative stress and regression of RAS-driven tumors. Cancer Discov. 2017, 7, 1450-1463. [CrossRef]

166. Matheson, C.J.; Backos, D.S.; Reigan, P. Targeting WEE1 Kinase in Cancer. Trends Pharmacol. Sci. 2016, 37, 872-881. [CrossRef]

167. Hai, J.; Liu, S.; Bufe, L.; Do, K.; Chen, T.; Wang, X.; Ng, C.; Li, S.; Tsao, M.S.; Shapiro, G.I.; et al. Synergy of WEE1 and mTOR inhibition in mutant KRAS-driven lung cancers. Clin. Cancer Res. 2017, 23, 6993-7005. [CrossRef] [PubMed]

168. Meng, J.; Dai, B.; Fang, B.; Nebiyou Bekele, B.; Bornmann, W.G.; Sun, D.; Peng, Z.; Herbst, R.S.; Papadimitrakopoulou, V.; Minna, J.D.; et al. Combination treatment with MEK and AKT inhibitors is more effective than each drug alone in human non- small cell lung cancer in vitro and in vivo. PLoS ONE 2010, 5, 14124. [CrossRef]

169. Halilovic, E.; She, Q.B.; Ye, Q.; Pagliarini, R.; Sellers, W.R.; Solit, D.B.; Rosen, N. PIK3CA mutation uncouples tumor growth and cyclin D1 regulation from MEK/ERK and mutant KRAS signaling. Cancer Res. 2010, 70, 6804-6814. [CrossRef] [PubMed]

170. Tolcher, A.W.; Khan, K.; Ong, M.; Banerji, U.; Papadimitrakopoulou, V.; Gandara, D.R.; Patnaik, A.; Baird, R.D.; Olmos, D.; Garrett, C.R.; et al. Antitumor activity in ras-driven tumors by blocking akt and mek. Clin. Cancer Res. 2015, 21, 739-748. [CrossRef] [PubMed]

171. Yap, T.A.; Bjerke, L.; Clarke, P.A.; Workman, P. Drugging PI3K in cancer: Refining targets and therapeutic strategies. Curr. Opin. Pharmacol. 2015, 23, 98-107. [CrossRef]

172. Ramanathan, R.K.; Von Hoff, D.D.; Eskens, F.; Blumenschein, G.; Richards, D.; Genvresse, I.; Reschke, S.; Granvil, C.; Skubala, A.; Peña, C.; et al. Phase Ib Trial of the PI3K Inhibitor Copanlisib Combined with the Allosteric MEK Inhibitor Refametinib in Patients with Advanced Cancer. Target. Oncol. 2020, 15, 163-174. [CrossRef] [PubMed]

173. Ischenko, I.; Petrenko, O.; Hayman, M.J. A MEK/PI3K/HDAC inhibitor combination therapy for KRAS mutant pancreatic cancer cells. Oncotarget 2015, 6, 15814-15827. [CrossRef]

174. Teh, J.L.F.; Cheng, P.F.; Purwin, T.J.; Nikbakht, N.; Patel, P.; Chervoneva, I.; Ertel, A.; Fortina, P.M.; Kleiber, I.; HooKim, K.; et al. In vivo E2F reporting reveals efficacious schedules of MEK1/2-CDK4/6 targeting and mTOR-s6 resistance mechanisms. Cancer Discov. 2018, 8, 568-581. [CrossRef]

175. Affolter, A.; Drigotas, M.; Fruth, K.; Schmidtmann, I.; Brochhausen, C.; Mann, W.J.; Brieger, J. Increased radioresistance via G12S K-Ras by compensatory upregulation of MAPK and PI3K pathways in epithelial cancer. Head Neck 2013, 35, 220-228. [CrossRef]

176. Ras Mediates Radioresistance through Both Phosphatidylinositol 3-Kinase-Dependent and Raf-Dependent but Mito-GenActivated Protein Kinase/Extracellular Signal-Regulated Kinase Kinase-Independent Signaling Pathways. Available online: https:/ / pubmed.ncbi.nlm.nih.gov/12124353/ (accessed on 8 May 2021).

177. Wegman, P.; Ahlin, C.; Sorbe, B. Genetic alterations in the K-Ras gene influence the prognosis in patients with cervical cancer treated by radiotherapy. Int. J. Gynecol. Cancer 2011, 21, 86-91. [CrossRef]

178. Kim, T.J.; Lee, J.W.; Song, S.Y.; Choi, J.J.; Choi, C.H.; Kim, B.G.; Lee, J.H.; Bae, D.S. Increased expression of pAKT is asso-ciated with radiation resistance in cervical cancer. Br. J. Cancer 2006, 94, 1678-1682. [CrossRef]

179. Fraser, M.; Harding, S.M.; Zhao, H.; Coackley, C.; Durocher, D.; Bristow, R.G. MRE11 promotes AKT phosphorylation in direct response to DNA double-strand breaks. Cell Cycle 2011, 10, 2218-2232. [CrossRef]

180. Yang, L.; Yang, G.; Ding, Y.; Dai, Y.; Xu, S.; Guo, Q.; Xie, A.; Hu, G. Inhibition of PI3K/AKT signaling pathway radiosensi-tizes pancreatic cancer cells with ARID1A deficiency in vitro. J. Cancer 2018, 9, 890-900. [CrossRef] [PubMed]

181. Toulany, M.; Iida, M.; Keinath, S.; Iyi, F.F.; Mueck, K.; Fehrenbacher, B.; Mansour, W.Y.; Schaller, M.; Wheeler, D.L.; Rodemann, H.P. Dual targeting of PI3K and MEK enhances the radiation response of K-RAS mutated non-small cell lung cancer. Oncotarget 2016, 7, 43746-43761. [CrossRef] 
182. Bedard, P.L.; Tabernero, J.; Janku, F.; Wainberg, Z.A.; Paz-Ares, L.; Vansteenkiste, J.; Van Cutsem, E.; Pérez-García, J.; Stathis, A.; Britten, C.D.; et al. A Phase Ib dose-escalation study of the oral pan-PI3K inhibitor buparlisib (BKM120) in combination with the oral MEK1/2 inhibitor trametinib (GSK1120212) in patients with selected advanced solid tumors. Clin. Cancer Res. 2015, 21, 730-738. [CrossRef]

183. Goulielmaki, M.; Assimomytis, N.; Rozanc, J.; Taki, E.; Christodoulou, I.; Alexopoulos, L.G.; Zoumpourlis, V.; Pintzas, A.; Papahatjis, D. DPS-2: A Novel Dual MEK/ERK and PI3K/AKT Pathway Inhibitor with Powerful Ex Vivo and In Vivo An-ticancer Properties. Transl. Oncol. 2019, 12, 932-950. [CrossRef] [PubMed]

184. Sessa, C.; Shapiro, G.I.; Bhalla, K.N.; Britten, C.; Jacks, K.S.; Mita, M.; Papadimitrakopoulou, V.; Pluard, T.; Samuel, T.A.; Akimov, M.; et al. First-in-human phase I dose-escalation study of the HSP90 inhibitor AUY922 in patients with advanced solid tumors. Clin. Cancer Res. 2013, 19, 3671-3680. [CrossRef] [PubMed]

185. Doi, T.; Onozawa, Y.; Fuse, N.; Yoshino, T.; Yamazaki, K.; Watanabe, J.; Akimov, M.; Robson, M.; Boku, N.; Ohtsu, A. Phase I dose-escalation study of the HSP90 inhibitor AUY922 in Japanese patients with advanced solid tumors. Cancer Chemother. Pharm. 2014, 3, 629-636. [CrossRef] [PubMed]

186. Park, K.S.; Oh, B.; Lee, M.H.; Nam, K.Y.; Jin, H.R.; Yang, H.; Choi, J.; Kim, S.W.; Lee, D.H. The HSP90 inhibitor, NVP-AUY922, sensitizes KRAS-mutant non-small cell lung cancer with intrinsic resistance to MEK inhibitor, trametinib. Cancer Lett. 2016, 372, 75-81. [CrossRef]

187. Park, K.S.; Yang, H.; Choi, J.; Seo, S.; Kim, D.; Lee, C.H.; Jeon, H.; Kim, S.W.; Lee, D.H. The HSP90 inhibitor, NVP-AUY922, attenuates intrinsic PI3K inhibitor resistance in KRAS-mutant non-small cell lung cancer. Cancer Lett. 2017, 406, 47-53. [CrossRef]

188. Turk, M.; Tatli, O.; Alkan, H.F.; Ozfiliz Kilbas, P.; Alkurt, G.; Dinler Doganay, G. Co-Chaperone Bag-1 Plays a Role in the Autophagy-Dependent Cell Survival through Beclin 1 Interaction. Molecules 2021, 26, 854. [CrossRef] [PubMed]

189. Guo, J.Y.; Chen, H.Y.; Mathew, R.; Fan, J.; Strohecker, A.M.; Karsli-Uzunbas, G.; Kamphorst, J.J.; Chen, G.; Lemons, J.M.S.; Karantza, V.; et al. Activated Ras requires autophagy to maintain oxidative metabolism and tumorigenesis. Genes Dev. 2011, 25, 460-470. [CrossRef] [PubMed]

190. Kinsey, C.G.; Camolotto, S.A.; Boespflug, A.M.; Guillen, K.P.; Foth, M.; Truong, A.; Schuman, S.S.; Shea, J.E.; Seipp, M.T.; Yap, J.T.; et al. Protective autophagy elicited by $\mathrm{RAF} \rightarrow \mathrm{MEK} \rightarrow \mathrm{ERK}$ inhibition suggests a treatment strategy for RAS-driven cancers. Nat. Med. 2019, 25, 620-627. [CrossRef] [PubMed]

191. Yao, W.; Yue, P.; Zhang, G.; Owonikoko, T.K.; Khuri, F.R.; Sun, S.Y. Enhancing therapeutic efficacy of the MEK inhibitor, MEK162, by blocking autophagy or inhibiting PI3K/Akt signaling in human lung cancer cells. Cancer Lett. 2015, 364, 70-78. [CrossRef]

192. Bryant, K.L.; Stalnecker, C.A.; Zeitouni, D.; Klomp, J.E.; Peng, S.; Tikunov, A.P.; Gunda, V.; Pierobon, M.; Waters, A.M.; George, S.D.; et al. Combination of ERK and autophagy inhibition as a treatment approach for pancreatic cancer. Nat. Med. 2019, 25, 628-640. [CrossRef]

193. Lee, C.S.; Lee, L.C.; Yuan, T.L.; Chakka, S.; Fellmann, C.; Lowe, S.W.; Caplen, N.J.; McCormick, F.; Luo, J. MAP kinase and autophagy pathways cooperate to maintain RAS mutant cancer cell survival. Proc. Natl. Acad. Sci. USA 2019, 116, 4508-4517. [CrossRef]

194. Yanae, M.; Tsubaki, M.; Satou, T.; Itoh, T.; Imano, M.; Yamazoe, Y.; Nishida, S. Statin-induced apoptosis via the suppression of ERK1/2 and Akt activation by inhibition of the geranylgeranyl-pyrophosphate biosynthesis in glioblastoma. J. Exp. Clin. Cancer Res. 2011, 30, 1-8. [CrossRef] [PubMed]

195. Iizuka-Ohashi, M.; Watanabe, M.; Sukeno, M.; Morita, M.; Hoang, N.T.H.; Kuchimaru, T.; Kizaka-Kondoh, S.; Sowa, Y.; Sakaguchi, K.; Taguchi, T.; et al. Blockage of the mevalonate pathway overcomes the apoptotic resistance to MEK inhibitors with suppressing the activation of Akt in cancer cells. Oncotarget 2018, 9, 19597-19612. [CrossRef] [PubMed]

196. Huang, X.; Huang, J.; Du, J.; Zhang, N.; Long, Z.; Yang, Y.; Zhong, F.; Zheng, B.; Shen, Y.; Huang, Z.; et al. Autophagy inhibitors increase the susceptibility of KRAS-mutant human colorectal cancer cells to a combined treatment of 2-deoxy-D-glucose and lovastatin. Acta Pharmacol. Sin. 2021, 1-13. [CrossRef]

197. Hemminki, O.; Dos Santos, J.M.; Hemminki, A. Oncolytic viruses for cancer immunotherapy. J. Hematol. Oncol. 2020, 13, 1-15. [CrossRef] [PubMed]

198. Beck, J.D.; Reidenbach, D.; Salomon, N.; Sahin, U.; Türeci, Ö.; Vormehr, M.; Kranz, L.M. mRNA therapeutics in cancer immunotherapy. Mol. Cancer 2021, 20, 69. [CrossRef]

199. Alabi, S.B.; Crews, C.M. Major advances in targeted protein degradation: PROTACs, LYTACs, and MADTACs. J. Biol. Chem. 2021, 296, 100647. [CrossRef] [PubMed]

200. Cai, J.; Lin, K.; Cai, W.; Lin, Y.; Liu, X.; Guo, L.; Zhang, J.; Xu, W.; Lin, Z.; Wong, C.W.; et al. Tumors driven by RAS signaling harbor a natural vulnerability to oncolytic virus M1. Mol. Oncol. 2020, 14, 3153-3168. [CrossRef]

201. Deng, H.; Liu, H.; de Silva, T.; Xue, Y.C.; Mohamud, Y.; Ng, C.S.; Qu, J.; Zhang, J.; Jia, W.W.G.; Lockwood, W.W.; et al. Coxsackievirus Type B3 Is a Potent Oncolytic Virus against KRAS-Mutant Lung Adenocarcinoma. Mol. Ther. Oncolytics 2019, 14, 266-278. [CrossRef] [PubMed]

202. Phelps, M.P.; Yang, H.; Patel, S.; Rahman, M.M.; McFadden, G.; Chen, E. Oncolytic Virus-Mediated RAS Targeting in Rhabdomyosarcoma. Mol. Ther. Oncolytics 2018, 11, 52-61. [CrossRef]

203. Kargbo, R.B. PROTAC-Mediated Degradation of KRAS Protein for Anticancer Therapeutics. ACS Med. Chem. Lett. 2020, 11, 5-6. [CrossRef] 
204. Bond, M.J.; Chu, L.; Nalawansha, D.A.; Li, K.; Crews, C.M. Targeted Degradation of Oncogenic KRASG12Cby VHL-Recruiting PROTACs. ACS Cent. Sci. 2020, 6, 1367-1375. [CrossRef]

205. Sahin, U.; Oehm, P.; Derhovanessian, E.; Jabulowsky, R.A.; Vormehr, M.; Gold, M.; Maurus, D.; Schwarck-Kokarakis, D.; Kuhn, A.N.; Omokoko, T.; et al. An RNA vaccine drives immunity in checkpoint-inhibitor-treated melanoma. Nature 2020, 585, 107-112. [CrossRef] [PubMed]

206. Chen, Y.; Gao, M.; Huang, Z.; Yu, J.; Meng, X. SBRT combined with PD-1/PD-L1 inhibitors in NSCLC treatment: A focus on the mechanisms, advances, and future challenges. J. Hematol. Oncol. 2020, 13, 1-17. [CrossRef] 